\title{
DEFENDING ABUSED WOMEN: BEGINNING A CRITIQUE OF NEW ZEALAND CRIMINAL LAW
}

\author{
Elisabeth McDonald*
}

The role of abuse in the lives of women who offend has been an issue in a number of recent high profile cases. This article considers the application of a number of defences to cases of violent female offending and concludes that the substantive law does not adequately address the abusive context in which women, as opposed to men, commit criminal acts.

\section{INTRODUCTION}

[T]here is a major problem confronting women who seek to rely on...criminal defences. It is that these defences have been developed through a long history of judicial precedents on the basis of male experiences and definitions of situations. Consequently female defendants whose experiences and definitions fall outside these male-inspired defences are confronted with the prospect of either failing to plead them successfully or having to distort their experiences in order to fit them into the defences. ${ }^{1}$

It is now recognised that most women kill for different reasons than men. ${ }^{2}$ It is also argued, although perhaps not so widely accepted, that women also offend for different

* Senior Lecturer in Law, Victoria University/Policy and Research Manager, Evidence Project, New Zealand Law Commission. Parts of this article have formed the basis of discussion in chapter 5 of Women in the Criminal Justice System (New Zealand Law Society, Wellington, 1997).

1 S Yeo "Resolving Gender Bias in Criminal Defences" (1993) 19 Monash LR 104. See also I LeaderElliott "Battered But Not Beaten: Women Who Kill In Self Defence" (1993) 15 Sydney LR 403, 405: "The policies which shaped the modern law of self defence and provocation developed without reference to the very different patterns of homicide when men are killed by women."

2 "When men kill their wives they are often separated from them and the dispute is related to issues of exclusivity and child custody. Women rarely kill over sexual jealousy or following termination of the relationship and the killing is nearly always preceded by a high degree of violence." C Wells "Battered Woman Syndrome and the Defences to Homicide: Where to Now?" (1994) 14 Legal Studies 266. See also: E Hore, J Gibson and S Bordow Domestic Homicide 
reasons. ${ }^{3}$ The impact of abuse (sexual, violent, psychological) and poverty on women's lives is gradually being considered in the context of the criminal law. Women have long been participants in the criminal justice system as complainants, victims/survivors of abuse, but the argument that abuse may also contribute to female offending is a recent one. ${ }^{4}$

Abuse and poverty may also combine to place financial pressure on women to break the law in order to provide for their family - the recent cases of Ruka $v D S W^{5}$ and DSW $v$ Te Mounanui ${ }^{6}$ are compelling examples of this dynamic. The economic position of women ${ }^{7}$ (especially those providing for children) together with the prevalence of sexual and violent abuse of women by men they know $^{8}$ place women, including Maori women, ${ }^{9}$ under gender specific pressures which arguably lead women to offend in different ways and for different reasons than men.

In this article I discuss whether and how the current substantive New Zealand criminal law acknowledges the prior abuse of women offenders by examining the operation of the

(Family Court of Australia, Research Report 3, 1996); P Easteal Killing the Beloved: Homicide Between Adult Sexual Intimates (Australian Institute of Criminology, Canberra, 1993) and K Polk "Lethal Violence as a Form of Masculine Conflict Resolution" (1995) 28 Aust and NZ J of Criminology 93.

3 E Sommers Voices from Within: Women Who Have Broken the Law (University of Toronto Press, Toronto, 1995).

4 "We understand that a history of battering, previously invisible, can now be seen in women's criminal conduct in a wide variety of circumstances, and that many women who are in jail on charges that are seemingly unrelated to battering have been battered." E Schneider "Resistance to Equality" (1996) 57 Uni of Pitt LR 477, 489-90.

5 "The abuser generally exerts not only physical control but financial and social control also. Women in these relationships are frequently kept without money, are not allowed friends, and are forbidden to move outside the house without the knowledge of the dominant party." [1997] 1 NZLR 154, 171. For further discussion of this case see E McDonald "A Relationship in the Nature of Marriage: Ruka v Department of Social Welfare [1996] NZLJ 423.

6 [1996] DCR 387, 392.

7 J Morris Women's Access to Justice: He Putanga Mo Nga Wahine Ki Te Tika - Justice is Not Blind to the Effects of Gender (New Zealand Law Society, Conference Papers, Vol 1, Dunedin, 1996) Volume 1, 9, 10-11.

8 For example, see the statistics in N Seuffert "Lawyering for Women Survivors of Domestic Violence" (1996) 4 Waikato LR 1 and the recent findings in: A Morris Women's Safety Survey 1996 (Victimisation Survey Committee, Wellington, 1997).

9 Maori woman are also eleven times more likely than non-Maori women to be convicted of a "non-traffic" offence - see J Paulin and E Siddle Responding to Offending by Maori: Some Criminal Justice Statistics (Criminal Justice Policy Group, Ministry of Justice, 1996) 38 (Draft containing provisional results). 
defences of provocation, self defence, automatism and insanity. ${ }^{10} \mathrm{I}$ argue that the criminal law does not reflect an appropriate understanding of the dynamic of abuse and its effects on women's lives and women's offending and that the understanding of judges and juries is unnecessarily limited by the current use of expert evidence. I conclude that, because women's experiences of sexual and physical abuse contributes to their offending in gender-specific ways, the criminal law should be amended or interpreted in a way that acknowledges the effects of such abuse as it acknowledges the principal excuses for "male" offending. Some examples of proposed reform are also discussed.

\section{WOMEN WHO KILL THEIR ABUSERS}

Most women kill their partners because they know they or their children are going to die. I have never met a man who killed his partner because he thought he was in physical danger. $^{11}$

Abused woman in New Zealand have killed their abusers. Whether such killings should be viewed by the law as "justified" (in self defence) or "excusable" (as provoked) or punishable as intentional killing is a debate that has split the profession and the public. ${ }^{12}$

The issue that has been the focus of the debate has been the relevance of the context of abuse to the case against the woman offender and her punishment. In recent years, the effect of this context of abuse has been introduced into the trial as expert evidence of the so called "battered woman syndrome" (BWS).

\section{A The Role of Expert Evidence of "Battered Woman Syndrome"}

Expert evidence concerning BWS has been admitted by New Zealand courts as relevant to a number of different issues, including the perception of imminence in relation to self-

10 For discussion of the role of abuse and the defence of compulsion see: E McDonald "Women Offenders and Compulsion" [1997] NZLJ 402.

11 S Osthoff, Director of the National Clearinghouse for the Defence of Battered Women (USA), cited in M Hooper "When Domestic Violence Diversion is No Longer an Option: What to do with the Female Offender?" (1996) 11 Berkeley Women's LJ 168, fn 33 . Note also an Australian study which concluded that possessiveness is a major feature of male violence, whereas in six out of the seven cases in which a woman had killed her male partner there was evidence that the woman had acted in self protection against a violent and abusive partner. See K Polk and D Ranson "The Role of Gender in Intimate Homicide" (1991) 24 Aust and NZ J of Crim 15.

12 See for example, F Wright "Self Defence and the Classification of Defences" (1992) 7 AULR 127, 136ff and R Schopp, B Strugis and M Sullivan "Battered Woman Syndrome, Expert Testimony, and the Distinction Between Justification and Excuse" [1994] Uni of Illinois LR 45. 
defence ${ }^{13}$ and the presence of "a relationship in the nature of a marriage."14 Expert evidence describing the syndrome has been admitted because it has been argued it is beyond the common understanding of the jury ${ }^{15}$ and that it will therefore assist the jury in understanding why the woman behaved in a certain way, behaviour which may otherwise be contrary to expectations. ${ }^{16}$ This is sometimes referred to as "counter-intuitive" evidence. For example, it is argued in support of admitting such evidence that many people do not understand why woman do not leave an abusive relationship, and jurors may attempt to explain this by categorising the woman as either someone who enjoys being beaten, or a liar who has exaggerated the extent of the abuse ${ }^{17}$ It may therefore be of considerable assistance to a woman's defence for the jury to be educated about the effects of abuse, to know that men threaten and pursue their absent wives, and that the option of leaving home is neither emotionally or economically straightforward. ${ }^{18}$

Although it is undoubtedly useful for juries to be educated in this way, there has been much criticism of the reliance on evidence of BWS as a way of explaining the dynamics of abusive relationships. ${ }^{19}$ The main concerns are that rather than an abed woman being presented as "a normal, reasonable person, caught in irrational circumstances, responding as any reasonable person would", 20 as a sufferer of a syndrome she is represented as mentally unstable. The indicators of the syndrome may also not be present in the conduct of many abused women, which may then deny them a defence and their abuse may not be used to explain or excuse their actions. The fact that a woman may not "fit" the profile of a battered woman as defined by the syndrome may also be used against women who are victims, rather than offenders. Such an approach was taken in the criminal trial of OJ

13 Oakes [1995] 2 NZLR 673; Wang [1990] 2 NZLR 529.

14 Ruka, above $\mathrm{n} 5$.

15 See generally L Etlinger "Social Science Research in Domestic Violence Law: A Proposal to Focus on Evidentiary Use" (1995) 58 Albany LR 1259.

16 AM Montgomery "State $v$ Riker, Battered Women Under Duress: The Concept the Washington State Court Could Not Grasp" (1996) 19 Puget Sound LR 385, 397-398; I Freckleton “When Plight Makes Right - The Forensic Abuse Syndrome" (1994) 18 Crim LJ 29, 40 and 48.

17 K O'Donovan "Law's Knowledge: The Judge, the Expert, the Battered Woman and Her Syndrome" (1993) $20 \mathrm{~J}$ of Law and Society 427, 430.

18 C Wells, above $\mathrm{n} 2,274$.

19 See for example E Sheehy, J Stubbs and J Tolmie in "Defending Battered Woman on Trial: The Battered Woman Syndrome and its Limitations" (1992) 16 Crim LJ 369; Celia Wells, above $n 2$.

20 M Dowd "Dispelling the Myths about the 'Battered Woman's Defence': Towards a New Understanding" (1992) 19 Fordham Urb LJ 567, 574. 
Simpson. The defence called an expert witness to support their argument that Nicole Brown Simpson did not suffer from BWS therefore she was not a battered woman which (arguably) made it less likely that OJ, allegedly her abuser on previous occasions, had killed her. ${ }^{21}$

As noted more recently, a significant local difficulty with inappropriate use or undue reliance on syndrome evidence is that: ${ }^{22}$

BWS evidence interacts with cultural, gender stereotypes with the result that women who kill abusers now have to fit within an "abused woman" straightjacket. This corresponds to a stereotype of a white, middle-class woman and stresses passivity, docility and helplessness. It excludes the experience of Maori women...whose experience of abuse is also shaped by racism.

Marewa Glover, for example, argues against the general applicability of the description of BWS, having found in her work with Maori women that abuse by male partners was constant rather than cyclical and took the form of a downward spiral. ${ }^{23}$

Recent Canadian research into the validity of these feminist concerns over the reliance on expert evidence of BWS by women defendants also concluded: ${ }^{24}$

Women with alcohol or drug problems, who use profane language, or who are involved in illegal activities may thus have less success using the battered woman syndrome, not because their self-defence claims are less valid, but because juries may be less likely to view them as deserving battered wives.

It is argued that for there to be appropriate reliance on the effects of battering there should no longer be references to a "syndrome" and expert explanations in terms of social

21 M Griffith "Battered Woman Syndrome: A Tool for Batterers?" (1995) 64 Fordham LR 141.

22 S Beri "Justice for Women Who Kill: A New Way?" (1997) 8 Aust Fem LJ 113, 123. See also J Stubbs and J Tolmie "Race, Gender and the Battered Woman Syndrome: An Australian Case Study" (1995) 8 Can J of Woman and the Law 122.

23 S Beri Justice for Women: A submission in support of a review of cases of women who are in New Zealand prisons for offending which relates to abuse (Women's Justice Service, Christchurch, 1997) 19.

24 M Schaffer "The Battered Woman Syndrome: Some Complicating Thoughts Five Years After $R v$ Lavallee" (1997) 47 University of Toronto LR 1, 14. 
problems rather than individual pathology should be admissible. ${ }^{25}$ This was acknowledged recently by Thomas J: ${ }^{26}$

[W]hile the syndrome represents an acute form of the battering relationship...it is probably preferable...to avoid reference to it and to speak simply of the battering relationship. There is a danger that in being too closely defined, the syndrome will come to be too rigidly applied by the Courts. Moreover, few aspects of any discipline remain static, and further research and experience may well lead to developments and changed or new perceptions in relation to the battering relationship and its effects on the mind and the will of women in such relationships... It is not, therefore simply a matter of ascertaining whether a woman is suffering from battered woman's syndrome and, if so, treat that as an exculpatory factor. What is important is that the evidence establish that the battered woman is suffering from symptoms or characteristics which are relevant to the particular case.

Evidence which may be of more assistance is that which focuses "on the defendant's circumstances and alternatives rather than her psychological state." ${ }^{27}$ Counsel should also seek to introduce "background evidence about the prevalence of violence, the economic dependency of women and their expected roles as home and family makers." 28

A different approach to the kind of evidence which is introduced to help a jury understand the situation and mental state of a battered woman may also respond to arguments that BWS is not an appropriate subject for expert evidence ${ }^{29}$ and prevent the use

25 K Budrikis "Note on Hickey: The Problems with a Psychological Approach to Domestic Violence (1993) 15 Sydney LR 365.

26 Ruka, above n 5, 173-174 (emphasis added).

27 Sheehy et al, above $n$ 19, 394 (emphasis added). See also Leader-Elliott, above n 1, 418: "The simplest and most nearly accurate explanation of a woman's choice to remain may be found in her belief that her life in that relationship, and the relationship itself, is still worth defending. There is no reason to assume...that she stayed because she was psychologically incapable of leaving or that her choice to remain was irrational or pathological."

$28 \mathrm{C}$ Wells, above $\mathrm{n} 2,275$. This is also the argument made more recently by M Raeder - see "The Double-Edged Sword: Admissibility of Battered Woman Syndrome By and Against Batterers in Cases Implicating Domestic Violence" (1996) 67 Uni of Colorado LR 789.

29 I Freckelton "When Plight Makes Right - The Forensic Abuse Syndrome" (1994) 18 Crim LJ 29; "Battered Woman's Syndrome - Dangerous Myth or Reality?" The Evening Post, Wellington, New Zealand, 20 November 1996. 
of BWS in other contexts to establish that a woman was not abused, because she was not diagnosed as having the syndrome. ${ }^{30}$

A recent study with mock jurors, however, found that there was no significant difference in terms of verdict choice or juror judgments when the presented expert testimony discussed "battered woman syndrome" rather than "social agency". The study concluded however that "the more important aspects of the testimony for jurors is the information provided about the limited choices confronting battered women in their attempts to end the abuse." 31 This finding emphasises the desirability of introducing evidence about the effects of abuse in a way that does not require women to meet a certain standard or diagnostic criteria.

Although the role of abuse has been acknowledged in a number of New Zealand cases, it has usually occurred solely through the use of expert evidence of BWS. The limitations of expert evidence concerning BWS is therefore apparent in much of the case law dealing with defences, which is discussed in the following sections.

\section{B Representations of Woman-Abuse in the Law of Self Defence}

Apart from lack of intent, involuntariness and insanity, the only complete defence to murder is self defence. It is unknown whether any woman in New Zealand who has killed her batterer has been acquitted on the grounds of self defence. ${ }^{32}$ The argument has certainly been made in a number of high profile cases, the most recent being $R v$ Oakes. ${ }^{33}$ The issue in these cases, where the defence has either been unsuccessful or has not been put to the jury, is whether the killing was "reasonable" in the circumstances. The question is familiar: is it justifiable for a battered woman who is not in "immediate" danger of death or grievous bodily harm to kill her batterer rather than leave to avoid certain death (as she perceives it) at some later time?

30 The difficult issues raised in the debate concerning the use of expert evidence concerning BWS are usefully illustrated by the most recent Court of Appeal case to discuss the admissibility of such evidence: $R v$ Guthrie, Unreported, 18 June 1997, Court of Appeal, CA 387/96.

31 R Schuller and P Hastings "Trials of Battered Woman Who Kill: The Impact of Alternative Forms of Expert Evidence" (1996) 20 Law and Human Behaviour 167, 183. For further discussion on the helpful use of expert testimony see M Raeder "The Better Way: The Role of Batterers' Profiles and Expert 'Social Framework' Background in Cases Implicating Domestic Violence" (1997) 68 Uni of Colorado LR 146.

32 Self defence was successfully relied on by a battered woman in an attempted murder case: $R v$ Zhou, Unreported, 8 October 1993, High Court, Auckland Registry, T 7/93. For commentary on this case see N Seuffert "Battered Women and Self Defence" (1997) 17 NZULR 320. 
The arguments are well-traversed. For the woman it is argued that (relying on the wording of section 48 of the Crimes Act 1961) ${ }^{34}$ in the circumstances as she believed them to be (that he would kill her when he woke up, ${ }^{35}$ in the morning, or some time soon ${ }^{36}$ ) she had no reasonable alternative to avoid her own death (or the death of her children) than to kill him, by means of a "pre-emptive strike". For the Crown it is argued that it is unreasonable to kill him when it is possible to retreat, by going to the police, to a neighbour, to a Women's Refuge or simply to sleep. ${ }^{37}$ To date, the Crown has had the best of the argument. The Court of Appeal has affirmed that to allow women in these situations to rely on self-defence is to "return to the law of the jungle." 38

Although the prevailing opinion (at least in New Zealand) ${ }^{39}$ has the appeal of valuing the batterer's life it does fail to acknowledge what women's groups, women's advocates and provocation case law has been indicating for some time: that the most dangerous time for an abused woman is the three months after she has left the relationship. ${ }^{40}$ Killing or violence in this time is known as "separation homicide" or "separation assault." 41 Most studies establish that the batterer stalks, harasses, attacks and sometimes kills his ex-partner in

34 Section 48 provides: Every one is justified in using, in the defence of himself or another, such force as, in the circumstances as he believes them to be it is reasonable to use.

35 Wang, above $\mathrm{n} 13$.

36 Oakes, above n 13, 678.

37 Wang, above n 13, 534 .

38 Wang, above n 13, 535. "In particular, though [the Court of Appeal] made no reference to its decision in Wang, the Oakes Court seems to have retreated from its uncompromising approach in the earlier case." K Dawkins "Criminal Law" [1996] NZLRev 31, 47.

39 In Australia and Canada, imminence has been construed more liberally - see the recent case of Secretary (1996) 20 Crim LJ 223, 224. "[T]he accused could legally defend herself against a threat of future harm, provided that the threat itself was current... [A] sleeping aggressor could have a 'present ability'...to execute a threat he had made prior to falling asleep."

40 "The evidence and other material put before the Court strongly suggests that a battered woman is at greatest risk when she leaves or attempts to leave the relationship." Ruka, above $n$ 5, 163 .

41 Sheehy et al, above $n$ 19, 394. "Separation homicide" is far too common. One Australian study found that in nearly half of the wife killings, the woman had either left or was in the process of leaving when she was killed. Wallace Homicide: The Social Reality (NSW Bureau of Crime Statistics and Research, 1986) 112. See also Leader-Elliott, above n 1, 403 and F Manning Self Defence and Provocation: Implications for Battered Women Who Kill and for Homosexual Victims (NSW Parliamentary Library Research Service, Briefing Paper No 33/96) 7-8. 
$75 \%$ or more of all cases. ${ }^{42}$ The inability of the courts to recognise and validate the abused woman's perception of the "imminent" danger amounts to a serious gap between the experience of women and the operation of the criminal law. It is only more recently that one judge of the Court of Appeal has acknowledged that a battered woman may be "bound to [a] relationship by fear resulting in a psychological paralysis" 43 so that the only way to avoid being killed is to kill.

The significant issue in relation to battered women and self defence is the credibility of the woman. Given that section 48 contains a subjective inquiry (in the circumstances as she believes them to be), when a woman kills a man rather than be killed it must be justified and reasonable. Although the Court of Appeal in Wang agreed with the trial judge that "no ordinary reasonable person...would...have believed it necessary to kill", therefore apparently making the finding that the objective limb of the section was not satisfied, the Court failed to give adequate weight to the subjective limb - "in the circumstances as she believed them to be". If an abused woman believes that there is no alternative but to kill in order to prevent her death or the death of her child then her actions must be reasonable. Such a fact scenario must be covered by section 48 , and the section, as worded rather than as interpreted, would clearly allow for such an outcome. That the Court of Appeal upheld a decision not to allow self defence to even be considered by the jury indicates that there was no real acceptance of the woman's story and of her belief. ${ }^{44}$ It is because of this credibility "gap" that evidence to enable the Court and the jury to assess the sincerity of that belief is essential. ${ }^{45}$ Evidence can assist the jury to understand how well an abused woman can predict the behaviour of an abuser and therefore be in the best position to know whether the threats are likely to be acted on. ${ }^{46}$

42 See for example, BJ Hart "The Legal Road to Freedom" in M Hansen and M Harway (eds) Battering and Family Therapy (Sage Publications, Newbury Park, California, 1993). For some Australian statistics see E Hore, J Gibson and S Bordow Domestic Homicide (Family Court of Australia, Research Report No 13, 1996).

43 Ruka, above n 5, 183.

44 Wang, above n 13.

45 An Australian study demonstrates the gap between law and reality: “[I]t is significant that...the situations in which the women found themselves were not considered by their lawyers as justifying a plea of self defence. This attitude stands in strong contrast to that of the women concerned, who viewed the homicides as acts of self preservation". Manning, above n 41, 15.

46 " $[I] t$ has been suggested that a battered woman's knowledge of her partner's violence is so heightened that she is able to anticipate the nature and extent (though not the onset) of the violence by his conduct beforehand." $R v$ Lavallee (1990) 1 SCR 852, 880 (cited in Oakes, above $n$ 
One commentator has argued that a battered woman's perception of imminence may be also more understandable if one: ${ }^{47}$

view[s] the battered woman as a hostage who is told she would be killed the next day and then strangles a sleeping guard in an effort to escape. The perception of the reality of this threat gained over time is thus accepted as sufficiently imminent to justify the use of whatever force is necessary to achieve freedom.

The importance of this particular inquiry (into the woman's perception of imminence) is clear. Advocates for battered women in such a position should endeavour to get admitted as much of the context of the offence as is possible, whether this is through direct evidence or expert opinion. The importance of this kind of evidence has been recognised by the Court of Appeal in Oakes: ${ }^{\mathbf{4 8}}$

It will be apparent that the syndrome has its greatest relevance to the defence of selfdefence, where the test is whether the force used is reasonable in the circumstances as the accused believes them to be...A woman suffering from the syndrome may genuinely perceive danger earlier than others would, and a threat of more serious harm than others might see. The reasonableness of her response is, in accordance with the section, to be judged in light of her perception.

Despite this statement, however, the Court of Appeal went on to hold that there was no misdirection even though there was only one brief reference to BWS in the trial judge's direction to the jury, and that was in relation to provocation. The impact of this omission has been noted: 49

13, 676). See also E Schneider "Describing and Changing: Women's Self-Defence Work and the Problem of Expert Testimony on Battering" (1986) 9 Women's Rights Law Reporter 195, 222.

47 Above n 20, 580.

48 Above n 13, 676. As Suzanne Beri notes, however, the emphasis on BWS in the judgment may mean the decision "may not benefit woman who kill abusive partners who are not 'diagnosed' as having BWS at the time of the killing." Above n 22, 120.

49 Above n 32, 322. See also Dawkins above n 38, 47: "All the same, it seems more than slightly precarious for the court to accept, on the one hand, the important explanatory effect of defence evidence to the contrary but then, on the other, to approve a direction that failed to leave that to the jury on two of the central issues in the case." ; and J Finn "Oakes: Case and Comment" (1995) 19 Crim LJ 291, 293: "It [the relevance of BWS to self defence] was a live issue, perhaps the most important live issue, in the trial. To say that this did not matter because the jury might not have taken a view of the evidence favourable to the defence is, with respect, wrong. Trial judges have an obligation to put to jurors the vital evidence on the major issues before them; appellate courts have a duty to see that this is done." 
[T] he crucial relevance of the entire context of abuse to Oakes' perception of the circumstances and therefore the reasonableness of a pre-emptive strike in self-defence was not clarified for the jury by the judge...[T]he jury may not have had any information on the reasonableness of a pre-emptive strike in the circumstances as Oakes believed them to be and the relevance of battered woman syndrome to those circumstances. Therefore it seems unlikely that the jury could have grasped the relevance of Oakes' and the expert's testimony as to [her] fear on the night of the killing and her possible perception, due to her ability to predict the abusive acts of Gardener, that he would kill her that night.

The Court of Appeal also stated that battered woman's syndrome "could provide a motive for murder", 50 a "remarkable" statement which is "contrary to all of the evidence given in the case, and other cases, about the nature of the effects of battered woman syndrome. ${ }^{.51}$ The decision has prompted this comment from a male academic. 52

Many writers have long suggested that the law and the courts alike do not provide fair trials for women who kill their abusers. Despite its statement of principle as to the effects of battered woman syndrome, the judgment in Oakes will do nothing to dispel their fears.

The final portion of the Court of Appeal judgment in Wang also reflects lack of understanding about the impact and effects of abuse. The Court approved the following comments of the sentencing Judge. ${ }^{53}$

I find it disturbing that even at this stage, long after the event, you should still say that you really felt that you had no option but to kill your husband...[T] here seems to me to be an absence of any real contrition that you took your husband's life. I think that this gives some insight into the degree of deliberation involved in your actions.

With respect, it appears wholly consistent with the appellant Xiao Jing's version of the events and her belief in the imminence of harm that she "should still say [she] had no option but to kill [her] husband." This statement seems to reflect the trial judge's disbelief of her story and it appears that she is to be punished twice for thinking something so incredible. First, by not allowing her belief to be considered by the jury as making out a claim of self defence (that would be a "return to the law of the jungle"), and secondly, by treating her belief as an aggravating element in sentencing her for manslaughter (provocation having

50 Above n 13, 683

51 Finn, above $n$ 49, 293.

52 Finn, above $n$ 49, 293.

53 Above n 13, 541 (emphasis added). This rationale was cited with apparent approval by the Court of Appeal and was seemingly not an issue for Wang's counsel. 
been accepted by the jury). Wang is a striking example of how a failure to understand or accept women's reality impacts on the possibility of a just result. The case also demonstrates that expert evidence on the generality of BWS alone does not adequately inform judges and jurors of the relevant effects of abuse.

\section{Is Woman-Abuse Provocative?}

Historically, [provocation as a defence] developed to excuse male murder of women, prompted by a threat to male control over women's sexuality, and/or a threat to male possession and ownership of women in heterosexual relationships. ${ }^{54}$

Only in more recent years have courts begun to recognise, haltingly and uncertainly, the possibility that resentment against continuing cruelty, abuse or exploitation might rank as the equivalent, in exculpatory effect, of jealous rage prompted by real or imagined infidelity. ${ }^{55}$

While currently offering the most hope for battered women...provocation is a defence which is premised upon and perpetuates male notions of violence. ${ }^{56}$

Provocation has been relied on more successfully than self-defence, both here ${ }^{57}$ and overseas, ${ }^{58}$ by battered woman who have killed. The interpretation and application of section 169 of the Crimes Act $1961,{ }^{59}$ which codifies this partial defence to murder has not,

54 Beri, above $\mathrm{n} 22,121$. See generally: E McDonald "Provocation, Sexuality and the Actions of 'Thoroughly Decent Men'" (1993) 9 Women's Studies Journal 126; S Edwards "The Gender Politics of Homicide" in Sex and Gender in the Legal Process (Blackstone Press Ltd, London, 1996) 393ff; V Nourse "Passion's Progress: Modern Law Reform and the Provocation Defence" (1997) 106 Yale LJ 1331; I Leader-Elliott "Passion and Insurrection in the Law of Sexual Assault" in N Naffine and R Owens (eds) Sexing the Subject of Law (Sweet \& Maxwell, Sydney, 1997) 149.

55 Leader-Elliott, above n 1, 405.

56 D Nicolson and R Sanghvi "More Justice for Battered Women" [1995] New LJ 1122, 1124.

57 Wang, above $\mathrm{n} 13$.

58 A Young "Conjugal Homicide and Legal Violence: A Comparative Analysis" (1993) 31 Osgoode Hall LJ 761.

59 Section 169 provides:

(1) Culpable homicide that would otherwise be murder may be reduced to manslaughter if the person who caused the death did so under provocation.

(2) Anything done or said may be provocation if -

(a) In the circumstances of the case it was sufficient to deprive a person having the power of self-ccntrol of an ordinary person, but otherwise having the characteristics of the offender, of the power of self-control; and

(b) It did in fact deprive the offender of the power of self-control and thereby induced him to commit the act of homicide. 
however, been clear or consistent. The difficult case law ${ }^{60}$ on this section has arguably not helped battered women who have tried to have their actions excused under this provision.

The particular difficulties for battered women who seek to rely on the defence is satisfying the two legal requirements. First there must be an identifiable provocative act which occurs immediately before the killing. ${ }^{61}$ Secondly, the killing must occur while the offender is in the heat of passion. ${ }^{62}$ These are sometimes referred to as the objective requirement (that there was an objectively provocative act) and the subjective requirement (that as a result of that provocation, the offender did in fact lose self-control). ${ }^{63}$

Although the immediacy requirement has been interpreted less strictly when it seems apparent that the provocation has been "re-kindled" by another act, 64 it seems apparent that women will usually kill an abuser after a long history of abuse, rather than one specific incident. ${ }^{65}$ In the case of battered women who kill their abusers, there will normally not be one sufficiently provocative "act" 66 (that is, an act that would cause an ordinary person to lose the power of self control). Further, battered women will often not kill in the heat of the moment, but after some time, when the batterer is asleep or drunk.

The lack of a sufficiently provocative act has been addressed by women's advocates in two ways. First, by arguing that although an ordinary person may not lose self control over the particular act (which may be, for example, throwing the dinner at the wall), in the context of an abusive relationship this may well be enough to "provoke" a battered wife. This argument is supported by the treatment of battered woman syndrome as a

60 Note the contradictory comments of the Court of Appeal in McCarthy [1992] 2 NZLR 550 while trying to clarify the approach in McGregor [1962] NZLR 1069. See also B Brown "Provocation Reconstructed: the McArthyisation of McGregor" [1993] NZ Recent LR 329; G Stanish "Whither Provocation?" (1993) 7 AULR 381 and most recently G Orchard "Provocation Recharacterisation of 'Charactersitics'" (1996) 6 Cant LR 202.

61 S Tarrant "The 'Specific Triggering Incident' in Provocation: Is the Law Gender Biased?" (1996) 26 WALR 190.

62 S Tarrant "Something is Pushing Them to the Side of their Own Lives: A Feminist Critique of Law and Laws" (1990) 20 WALR 573, 594.

63 It has recently been stated by JC Smith that evidence of BWS is "now relevant to both the objective and subjective tests." [1997] Crim LJ 760.

$64 \quad R v$ Taaka [1992] 2 NZLR 198.

65 D Nicolson and R Sanghvi "Battered Woman and Provocation: The Implications of $R v$ Ahluwalia" [1993] Crim LR 728, 730; S Tarrant "Provocation and Self Defence: A Feminist Perspective" (1990) 15 Alt LJ 147, 150.

66 Which can include words or conduct, or presumably an absence of either. 
"characteristic" which should be taken into account when judging the nature of the act. ${ }^{67}$ The second approach is to treat all the abusive acts together as the provocation, relying on the concept of "cumulative provocation." 68

In order to satisfy the requirement of a "sudden and temporary" loss of self control, advocates have argued that battered women are more likely to experience a slow build up of fear, despair and anger and they will usually act on this when the abuser is not able to fight back. This delay, which the law has treated as a "cooling down" period has historically denied many women access to the defence. ${ }^{69}$ Although the defence has been successfully used by battered woman, especially in England, ${ }^{70}$ it remains unclear to what extent this gendered response to violence (provocation) has been accepted: ${ }^{71}$

The stricture of sudden and temporary loss of self-control...still exerts itself as the most formidable obstacle on the minds of the jury and the issue of whether the battered fearful woman...can avail herself...of a slow burn as opposed to an explosion of rage is yet to be determined.

In relation to provocation, as with self defence, it is important that the jury receive enough information about the situation and experience of the (battered) woman in order to make informed decisions about the elements of the offence and the reasonableness of the woman's response: ${ }^{72}$

[I]nformation on battered women is not concerned with their capacity for self- control but rather with their response patterns when gravely provoked by their batterers. Without such information, there is a danger of jurors concluding that ordinary women behaving in the way the defendant did were in possession of their self-control. This would be the result of adhering solely to a male model of response patterns which views a time-lag from the

67 Nicolson, above $\mathrm{n} 65,733$.

68 "We find it difficult to exclude provocation in such a setting of a close human relationship in which there can be a buildup, over a period, of emotions, and a further incident can cause feelings of both parties to run high and trigger a loss of self control." $R v$ Pita (1989) 4 CRNZ 660, 665-666.

69 J Greene “A Provocation Defence for Battered Women Who Kill?" (1989) 12 Adel LR 145, 158.

70 Edwards, above n 54, 410; S Edwards "From Victim to Defendant: The Life Sentence of British Women" (1994) 26 Case Western Res J of International Law 261, 290.

71 S Edwards and C Walsh "The Justice of Retrial?" [1996] New LJ 857, 858 (commenting on the Sara Thornton re-trial).

72 S Yeo "Sex, Ethnicity, Power of Self-Control and Provocation Revisited" (1996) 18 Sydney LR $304,316$. 
provocative incident as constituting a regaining of self-control, having the opportunity to select a weapon and to attack the deceased in stealth as clear signs of being in possession of self-control, and so also with appearing calm during and after the act of killing. Yet, these are all typical response patterns of ordinary women when deprived of their self-control. Additionally, they are responses which fall within the realm of normality and therefore deserving of societal compassion.

The last two sentences of this quote further illustrate the apparently contradictory arguments that defence counsel need to make in the case of women who rely on provocation. The traditional application of the section requires demonstration of a loss of self-control yet the final violent response of a battered woman is often understandable and justifiable without more. However, women risk serious penalties if they do not attempt to satisfy the existing defences. Because of the difficulty abused women have in establishing the elements of the traditional defences and the fact that the defences do not acknowledge that their responses "fall within the realm of normality", there have been strong arguments for legislative reform. Two such proposals are outlined below.

Although the previous discussion has been primarily concerned with the availability of provocation to battered women who kill their batterers, women may of course kill to protect their children from abuse. In an abusive relationship, the children will also invariably be abused as well, even if they are "merely" witnesses to the abuse. ${ }^{73}$ It is unclear, however, whether the abuse of children alone would be a sufficiently provocative act to enable a woman to rely on the defence. Although most would agree that sexual abuse of your child would be (or should be) sufficient provocation in law, the one case (Brown) where a woman sought to rely on her belief in abuse (her heightened sensitivity to this was due to her own abuse) resulted in a murder verdict. ${ }^{74}$

Brown can be usefully compared to $R v$ Campbell, 75 where the provocation (an ambiguous but possibly homosexual advance) triggered a flash-back to earlier childhood abuse causing the male defendant to lose control and kill. There are arguable factual differences between the cases yet the basis of the claim is very similar. In Brown, however, it appears little was made of the cumulative effect of the events leading up to the killing, and yet the lengthy time frame which probably denied her the defence is wholly consistent with

73 T Pocock and F Cram "Children of Battered Women" (1996) 4 Waikato LR 77; J Nemeth Stimson and B Lee Ciyou "Representing the Abused Spouse in Child Custody Litigation" (1995) 9 American J of Family Law 113, 119: "[R]esearch done to date clearly indicates that witnessing domestic violence may be as harmful to children as actually being abused themselves."

$R v$ Brown Unreported, 11 April 1995, Court of Appeal, CA 93/94. 
a gendered response to ongoing abuse, seemingly not addressed by the proper authorities. In Campbell the frenzied, instantaneous killing to a far less objectively provocative act, ${ }^{76}$ satisfied the traditional application of the provision. There is, however, clearly an issue of equality when a woman who believes her child has been sexually abused (in part because of her own history of abuse) cannot make out a defence of provocation, yet a man (also abused as a child) who kills because a hand on his knee causes him to relive the abuse, can rely on the partial defence.

The case of Pauline Brown illustrates the need for specific responses to women's offending, rather than requiring women to fit within existing defences. Two recent reform proposals addressing the position of abused women are discussed in the next section.

\section{LAW REFORM OPTIONS CONCERNING ABUSED WOMEN WHO KILL}

[T] he way forward for battered defendants remains either through development of the existing law on self defence or through a specific legislative defence. ${ }^{77}$

[T]he killing of a private tyrant is...a morally justified act. ${ }^{78}$

The previous discussion has examined the difficulties for women when attempting to rely on defences developed to respond to excusable male offending. As many women's groups believe that battered women who kill to protect themselves or their children from certain death or serious bodily injury should not be punished, there have been several proposals developed to achieve this outcome within the criminal law. Although the proposals vary in substance, they are consistent in recommending that there should be complete defence available to women in such situations ${ }^{79}$ - that is, their actions should be viewed as "justified" (like self defence) rather than "excused" as a recognition of human frailty (like provocation).

The 1987 Report of the South Australia Domestic Violence Council recommended that "a new complete defence be created which can be [relied] upon by a defendant charged with murder where the elements of such defence are a proven history of serious personal violence

76 "On the appellant's account the advance, if such it was, could fairly be described as mild or tentative." Above n 75, 26.

77 Above n 56, 1124.

78 J Maslow Cohen "Regimes of Private Tyranny: What Do They Mean to Morality and for the Criminal Law?" (1996) 57 Uni of Pitt LR 757.

79 The self preservation defence, as discussed below, has actually been put forward as a partial defence as a political tactic rather than what is probably appropriate. See Beri, above n 22, 118. 
by the deceased against the accused or against any child or children of the accused's household."80

In 1994 the Western Australian Task Force on Gender Bias, established by the Chief Justice of Western Australia, David Malcolm, recommended that a new defence be created to take account of the reality of the lives of women who kill abusers, so that "conduct is carried out by a person in self defence if the person is responding to a history of personal violence against herself... or another person and the person believes that the conduct was necessary to defend...herself or that other person against the violence." ${ }^{81}$ This formulation is, however, very similar to section 48 of the New Zealand Crimes Act 1961, the requirements of which have been difficult for women to satisfy because of how the courts have assessed their belief in imminence of harm and necessity. ${ }^{82}$

A more particularised defence has been proposed in England, ${ }^{83}$ Australia ${ }^{84}$ and in New Zealand: ${ }^{85}$ a defence of "self preservation". This defence would be available to any woman who caused the death of a person with whom she had a familial or intimate relationship and who subjected her to racial, sexual and/or physical abuse to the extent that she believed there was not protection or safety from the abuse and is convinced that the killing is necessary for self preservation. ${ }^{86}$ As Suzanne Beri says: ${ }^{87}$

[This] defence would be an important acknowledgement of the seriousness of male abuse of women and the real and serious effects on women's lives...[I]t would establish a necessary distinction between killing in response to a threat to esteem, power, control and possession

80 Cited in Manning, above n 41, 22.

81 Cited in Manning, above n 41, 22.

82 A woman's belief in necessity is usually assessed by external "appropriate" prior responses. This formulation leaves it unclear about how it will be satisfied - for example, how much previous violence does there have to be? Must the woman have tried to leave or seek help first? If so, how many times? Such uncertainty has historically worked against women.

83 By the London based Rights of Women Organisation (see Beri, above n 22, fn 2).

84 In submissions to the Australian Law Reform Commission, as reported in Equality Before the Law: Justice for Women (ALRC 69, Sydney, 1994) 277.

85 Proposed by the Women for Justice for Women Trust, based in Christchurch. As reported by Beri, above $\mathrm{n} 22,113$, they have received no response to their petition.

86 Above n 22, 114. Women for Justice for Women Trust is also proposing an extension to this to apply when women are acting to protect their children, or when a number of family members may act together to kill the abuser of them all (fn 11).

87 Above n 22, 124. 
(characteristic features of homicides [of women] committed by men) and killing arising from, and out of, a history of prolonged abuse and fear of future abuse (which tend to characterise homicides [of men] by women).

In a more recent proposal, ${ }^{88}$ the acknowledgement of male abuse of woman is taken further - it is the "tyrannical" behaviour of the man that would justify his killing: ${ }^{89}$

The condition that is necessary to the maintenance of a regime of private tyranny is that the life of at least one person who lives or formerly lived in the same household with the tyrant be subject to his domination and control in respect to such objectively important elements of everyday life that a reasonable member of society would not ordinarily consent to live under the same terms and conditions and would not view the consent of any other person to live under such circumstances as the rational exercise of choice...[T]he structure of private tyranny...is analogous...to voluntary slavery. It is not a subject to which the idea of consent lends any justificatory distinction.

Under this model, the focus of the inquiry is the behaviour is the "tyrant", not that of the abused woman. It is he who must fit the profile and then her response may be treated as understandable/excusable. This would also be the correct analysis of a hostage situation which seems the appropriate analogy, rather than the traditional legal analysis which requires the woman to be battered enough and to have tried hard enough to leave before her criminal actions may be excusable.

Either of these reform options are unlikely to be adopted in New Zealand in the near future, given that they recommend special treatment for women and require a significant shift in emphasis of the criminal law. That such a shift in emphasis may already be overdue is further illustrated by the treatment of women who seek to rely on the defences of insanity of automatism when they offend as the result of abuse. These cases are discussed in the next section.

88 Above $\mathbf{n} \mathbf{7 8}$.

89 Above n 78, 763. 


\section{ABUSE WHICH RESULTS IN OTHER OFFENDING}

\section{A Automatism Caused by the Trauma of Abuse}

Automatism as a defence to a criminal charge has been relied on in New Zealand courts, ${ }^{90}$ although it is extremely rare for automatism to be argued in a murder trial. ${ }^{91}$ There is some criticism of its use in the criminal law - it is argued that the legal concept of involuntariness is at variance with psychological and neurological knowledge, ${ }^{92}$ and that the crimes that can be committed by an unconscious will are very limited. ${ }^{93}$ In terms of the legal issues, it is still somewhat unclear whether a claim of automatism is relevant to the voluntary aspect of the act (which denies the actus reus of the offence) or whether it operates to support a claim that the act was not intentional. In any event, if successfully made out, (sane) automatism should result in an acquittal. ${ }^{94}$ The most significant issue is whether the cause of the "dissociative" state is external (when the automatism would be treated as sane) or internal (when insanity would be the appropriate defence). ${ }^{95}$ The distinction is significant for an accused, both in terms of outcome and the burden of proof. ${ }^{96}$

Automatism was, however, relied on in the Western Australian case of Falconer. ${ }^{97}$ In this case Mary Falconer, a 50 year old woman, shot her husband. She had no recollection of fetching the gun or firing it (she was in a dissociative state). The issue at trial was whether she intended to kill him. She was separated from her husband and had a non-

90 Burnskey v Police (1992) 8 CRNZ 582.

91 Some form of "involuntariness" was, however, argued (unsuccessfully) on appeal after the Campbell retrial: $R v$ Campbell (Unreported, 11 August 1997, Court of Appeal, CA 441/96).

92 EM Coles and D Jang "A Psychological Perspective on the Legal Concepts of 'Volition' and 'Intent"' (1996) $4 \mathrm{~J}$ of Law and Medicine 60.

93 "I take it as given that no man can find himself unwitting in the act of intercourse - ie, that penetration is an act which can not be done accidentally or by mistake." Pickard "Culpable Mistakes and Rape: Relating Mens Rea to the Crime" (1980) 30 Uni of Toronto LJ 75, 76. See also Daviault (1995) 93 CCC (3d) 21.

94 For a useful discussion on this topic see J Thompson "Post Traumatic Stress Disorder and Criminal Defences" (1991) 21 WALR 279 and "The Defence of Automatism" in RD Mackay Mental Condition Defences in the Criminal Law (Clarendon Press, Oxford, 1995) 1.

95 WJ Brookbanks "Criminal Law and Procedure" [1993] NZ Recent L Rev 44, 45; E McDonald "Acquittal for the Intoxicated Automaton?" [1993] NZLJ 44.

96 T Jones "Insanity, Automatism and the Burden of Proof on the Accused" (1995) 111 LQR 475.

97 The decision of the High Court of Australia is reported in (1990) 65 ALJR 20. See also P Aimes Fairall "Voluntariness, Automatism and Insanity: Reflections on Falconer" (1993) 17 Crim LJ 81. 
molestation order against him. There was a significant history of violence and abuse. He was facing charges of incest and Mary also thought he may well have abused a 7 year old girl in her care. Just before the killing he sexually assaulted Mary and taunted her that noone would believe her allegations of sexual abuse. He then went to grab her by the hair. She panicked and remembers nothing more until she was standing by his body with her discharged rifle in her hands.

The defence sought to raise the issue of involuntariness based on non-insane automatism. Evidence was presented in a voir dire from two psychiatrists. Both testified that she was sane at the time of the killing, although subject to a profound mental disturbance produced by psychological shock. The trial court refused to admit the medical evidence. On appeal the High Court of Australia held that the psychiatric evidence was wrongly excluded and the case was ordered to be re-tried, although the Court was divided on whether automatism caused by a psychological blow should be treated as insanity - the central problem remaining the difficulty of "distinguishing between a sound or healthy mind and a diseased mind." 98 On this issue Mason CJ stated: ${ }^{99}$

the difficulty [lies]in choosing between the reciprocal factors - the trauma and the natural susceptibility of the mind to affectation by psychological trauma - as in the case of the malfunction. Is one factor or the other the cause or are both to be treated as causes? To answer this problem, the law must postulate a standard of mental strength which, in the face of a given level of psychological trauma, is capable of protecting the mind from malfunction... That standard must be the standard of the ordinary person: if the mind's strength is below that standard, the mind is infirm; if it is above that standard, the mind is sound or sane. This is an objective standard which corresponds with the objective standard imported for the purpose of determining provocation.

This reference to a mind of ordinary firmness again raises the issue of the application of such a standard. ${ }^{100}$ If judges and juries do not understand how a person of "ordinary" firmness might respond as a result of constant abuse, how can their judgement about their mental state be fair (and objective)? In the words of Professor Robin West: "with the exception of Vietnam veterans, no white heterosexual man I have ever known knows what it feels like to be afraid all of the time. But many women - and there are many battered

98 Mackay, above n 94, 60.

99 Above $\mathrm{n}$ 97, 30 (emphasis added).

100 For a discussion of the relevance of age and ethnicity to the objective standard, see S Yeo "Power of Self-Control in Provocation and Automatism" (1992) 14 Sydney LR 3. 
woman - know what it means to define oneself in such a way as to make it possible to live with the truth that tomorrow you may die."101

Finally, there are other (evidential) difficulties with the defence of automatism for battered women who kill which have been cogently outlined by Stella Tarrant: ${ }^{102}$

[A] difficulty [also] arises where automatism is based on a dissociative state and severe domestic violence because of the tension between the evidence which supports the defence and the elements of the defence itself. Along with insanity, non-insane automatism is the ultimate statement of irresponsibility, or an unwilled, and in one sense unintended, act. An automaton does not will or, relevantly, want events to occur. Yet the evidence supporting a woman's claim of dissociation in this context is evidence suggesting, precisely, that she would want retaliation, that she would will and want harm to occur to the person she attacked. Thus the structure of the defence encourages a perception of her as a liar or as manipulating the facts - and if the abuse occurred and she did not harm she must surely be mad. The dichotomy between criminality and insanity becomes clearer.

\section{B Reliance on Insanity by Abused Women}

Recent case law concerning women who have offended in a disassociated state as a result of abuse indicates that insanity rather than automatism should be considered. The New Zealand cases on point over the last two years however, have not accepted either defence.

In 1989 in England a 23 year old stabbed a woman with a pen knife (causing a small puncture wound) in the course of a robbery. When first seen by the police, she was leaning against the victim's car saying "I'm ill, I'm ill". In front of the police she also mistook the woman she had assaulted for a man. On being arrested she was described as passive and indifferent and could only recollect some of the events. Subsequently a medical examination revealed that she had been violently raped three days prior to the offence and had not told anyone. A psychiatrist diagnosed that after the rape she was suffering from post traumatic stress disorder (also known as rape trauma syndrome) and was in a dissociative state and the offences had been committed during a psychogenic fugue. It was held that this, if accepted, would amount to sane automatism as the state had been caused by an external factor and the defence should be put to the jury. ${ }^{103}$

101 R West "The Difference in Women's Hedonic Lives: A Phenomenological Critique of Feminist Legal Theory" (1987) 3 Wisconsin Women's LJ 81.

102 S Tarrant “A New Defence in Spouse Murder?" (1992) 17 Alt LJ 67, 69.

$103 R v T[1990]$ Crim LR 256. 
More recently in New Zealand, ${ }^{104}$ a young woman set fire to a house occupied by two men who had raped and sodomised her while she was living in India (essentially as their prisoner). Although the sexual abuse had happened some time previously, her attack on the men's house seems to have been triggered by a fight with her boyfriend. ${ }^{105}$ In this case, however, her psychiatrist said that although she had developed post traumatic stress disorder, the offence was a product of a severe, disabling mental disorder that "substantially compromised her ability to know and understand the nature, quality and wrongfulness of her acts."106 The case then turned on whether the District Court had jurisdiction to make a treatment order under section 118 of the Criminal Justice Act 1985, clearly accepting that the facts made out a claim of insanity rather than non-insane automatism. Insanity was not accepted as a defence however, and the woman was later sentenced to five years' imprisonment - a sentence that is seemingly excessive compared to sentences for similar offences. ${ }^{107}$

Another case concerning a woman with a similar history of abuse was heard by Ellis J in March 1997. ${ }^{108}$ Susan Simms appealed her conviction for intentionally damaging five cars by scratching them as she walked past them. She claimed she was legally insane at the time. The trial judge had held that she had not established that she was "labouring under a disease of the mind."109

The expert psychological evidence offered on appeal indicated that Susan was suffering from "a borderline personality disorder and from post traumatic stress disorder"110 brought about by the sexual abuse she suffered as a young person and the loss of her mother. Her aggression in the past, observed during hospital visits to receive treatment for her drug and alcohol addiction, was directed at any male person who tried to offer her assistance. She had always apologised for her behaviour afterwards saying that she had a blackout and no memory of her behaviour. It was accepted by the psychologist that most people would have blacked out on the amount of alcohol and medication she had taken.

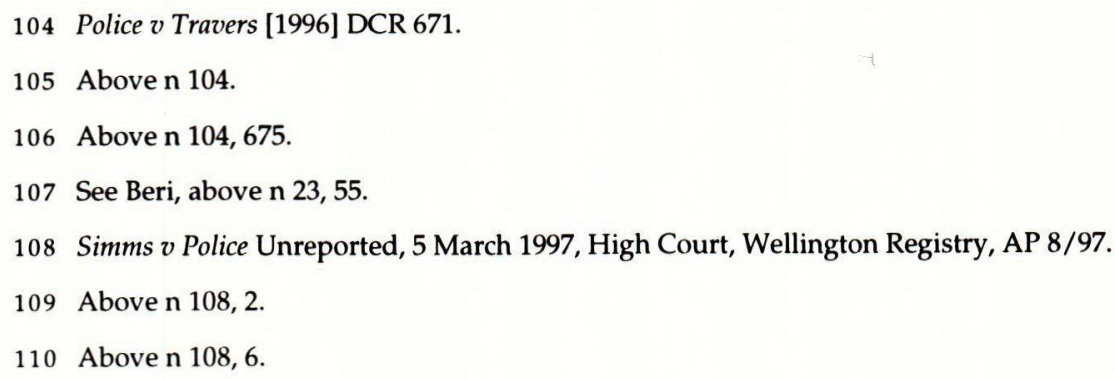


With regard to the car scratching incident, however, there was no evidence of such severe intoxication, although Susan claimed memory loss. At trial she accepted that she did the acts intentionally and did not claim that she was acting while in some automatic state. Her appeal failed as her ability to not know right from wrong at the time of the acts was not established.

A recent Court of Appeal case, $R v$ Hamblyn, ${ }^{111}$ held that the dissociative identity disorder (DID) suffered by the appellant could not found a defence of insanity. Although it was accepted that the offences (27 counts of using a document to obtain to obtain a pecuniary advantage) were committed by "alters" (other distinct personalities), the "alters" were not established to be insane at the time of the offending. Automatism was also not available as a defence as "the activities as carried out by the alters have been extended periods of purposeful, novel activity which has been complex and goal directed". 112

This case is significant because, although DID is rare, it is understood to be triggered by childhood trauma (usually sexual abuse). The disorder can lead to the development of "alters" within the overall personality to enable the child to cope with the trauma. "When the adult is in crisis, the personality will revert to the one that can 'cope' at the time and which will sometimes function independently and out of consciousness of the main personality."113

The Court of Appeal upheld the trial judges finding that neither insanity nor automatism was available on the facts. In concluding, the Court also stated that as DID covers a "wide spectrum of disability, from momentary lapse of awareness, such as are experienced by most people, through to extreme forms where other personalities operate singly or together", caution must be exercised. ${ }^{114}$ The Court clearly found as a matter of policy all people with DID could not be excused on the grounds of insanity, therefore neither could the particular defendant.

This decision, although arguably correct in law, sets a very high standard of proof for a person suffering from an extreme form of DID, acknowledged by all the experts involved in the case to be "a severe and disabling condition". ${ }^{115}$ In order to rely on a defence of insanity such a person must establish that "alter", of whom they have no memory, was insane at the

111 (1997) 15 CRNZ 58.

112 Above n 111, 8.

113 Above n 111, 5 .

114 Above n 111, 11.

115 Above n 111, 11. 
time they offended, offending of which the defendant has no knowledge. It may be that the law should not excuse every person who commits an offence while unaware of what they are doing, but it seems hard to justify convicting someone whose "alters" committed the crimes, "alters" who are the result of an extreme form of diassociation.

These recent cases indicate that abuse which contributes to offending will only be considered, if at all, as a mitigating factor, not an excuse. Although there may be policy reasons for limiting defences in this way, just results depend on sentencing judges receiving and understanding appropriate information about the context of abuse and its effects on the woman's life and her offending. In at least one of the cases noted above, the sentence length indicates this may not have occurred.

\section{CONCLUSION}

At least $80 \%$ of women in New Zealand prisons have been raped and sexually abused....When taking into account physical, psychological and emotional abuse, it is likely that $95-100 \%$ of women in prisons have been abused. ${ }^{116}$

New Zealand case law documents an inconsistent approach to women's offending. Some recent cases indicate that courts are willing and able to assess female criminality in its gender-specific context, a context that is crucial to consider when it includes domestic violence. Other decisions, however, fail to appropriately acknowledge the impact and effects of on-going abuse, either in mitigation or as relevant to the establishment of a defence.

In particular, the defences available to a charge of murder have not been applied so as to recognise the coercion and control exerted most often by men in their own homes over women they live with. These defences must be amended or interpreted in a way to excuse those women who have no real choice.

If the criminal law continues to misunderstand why women may offend, it will continue to recognise only "male" motivations for criminal actions. In doing so, it must fail to produce just results.

116 Above n 23, 41. 


\title{
AbILITy to PAy IN NEW ZEALAND'S TAX SYSTEM
}

\author{
Åsa Gunnarsson
}

This article begins with a review of tax distribution principles and theory to provide a framework to which the position and interpretation of the ability to pay principle can be related. In the next three sections I describe how the income tax base, the wealth tax and the income support system correspond with the ability to pay principle. Finally, I look upon new equity trends in taxation from a New Zealand perspective.

\section{STRUCTURES AND PRINCIPLES}

The reforms of the eighties and the beginning of the nineties among the OECD countries have been based on similar problems. The core of the problem was that the tax levels and the income tax structures were not in harmony. A progressive tax schedule, applied on a narrow tax base with a source dependent and source differentiated definition of income, was highly inefficient and distorting in the Paretian sense. The income tax structure was undermining itself. The solutions adopted can briefly be summarised: introduction of a comprehensive income tax base that, by definition, is very close to the Haig-Simons theoretical concept of income (net accretion of a spending unit's power to consume over some period of time, without distinctions as to source or use); a change in the mix of tax bases with a move from income tax towards consumption tax; the flattening of the income tax rates schedules or/and reduction in the number of tax brackets. ${ }^{1}$

These tax reforms, far reaching as they are in structural aspects, reflect changes in basic attitudes to tax policy, with corresponding changes in the level of principle. Horizontal fairness and tax neutrality have dominated at the cost of vertical equity and redistributive

- Dr Åsa Gunnarsson is a senior lecturer at the Department of Legal Science, University of Umeå, Sweden. The article is a result of an academic year as visiting fellow at the Law Faculty, Victoria University of Wellington, Te Kauhanganui Tatai Ture, Te Whare Wananga o te Upoko o te Ika a Maui. The author wishes to thank Professor John Prebble for good support during the year, and lecturer Sandra Petersson for detailed comments and valuable suggestions.

1 K Messere, Tax Policy in OECD Countries: Choices and Conflicts, (IBFD Publications BV, Amsterdam, 1993), 30-32, 38. 
elements in taxation. The conflict between the requirement of vertical equity and economic efficiency that for a long time has been presumed and predicted in theory is now confirmed in practice by the loss of vertical equity in the income tax structure and in the mix of tax bases. ${ }^{2}$ Changes in the position of different types of tax principles are of course not a new phenomenon. Such changes are expected in the legislative process of liberal democracies in a dynamically changing world. With respect to the pluralism of tax forms, pluralism may also be found with respect to fundamental principles of taxation. The different types of conflicting objectives that have emerged during the last period of tax reforms are in many ways connected to old and always ongoing basic issues of taxation.

At the most general level one finds the perennial conflict between the fundamental function of taxation, to provide revenue to finance public expenditures, and economic and social policy objectives that tend to reduce revenue collections. A principle issue of the same dimension and of the same importance over time is the distribution of the tax burden. The normative elements for distribution of the tax burden are horizontal and vertical equity, neutrality, and redistribution. These standards are in turn parts of a broad political, philosophical and economical context in both theory and practice. As society and theories have changed, the normative foundations of how to distribute the tax burden also have changed over time.

Equitable distribution, vertical or horizontal, is by definition related to the principles of ability, sacrifice, and benefit, and it reflects the need to justify taxation in the relation between state and citizen. Redistribution emerges from the use of taxation as an instrument for welfare policy. Neutrality is based on adjusting taxation to what is understood as an efficient allocation of resources in the market economy. Concepts of distributive justice and efficient allocation of resources represent different aspects of the function of public finance. These concepts may in certain cases even be conflicting.

In tax legislation, the concrete application of theoretical principles of equity, redistribution and neutrality takes place through applying principles of law on the basis of ethical, economical and political values and objectives. These fundamental principles of law therefore act as a meeting point between basic values and objectives of the legislation on the one hand, and the legal rules formed by statutes and case law on the other hand.

Whatever the choice of distributive principles, the choice must be based on theoretical and practical tax reform analysis to guide the structural changes in the way intended. The interpretation and implementation of principles must be clear and open so normative coherence can be achieved in the tax system in its entirety. The use of principles as a mere legitimising front creates instability. The equity principles support the justification of the

2 Above n1, 33-34, and Åsa Gunnarsson Skatterättvisa (Iustus, Uppsala, 1995) 283-289. 
tax legislation. This is a fundamental issue that no tax legislator in the world can ever get around.

\section{A The Principles of Equity}

The main contours of the different schools of tax theory are relatively easy to discern. This may be due to the fact that the number of original theoretical solutions to the distribution problem is limited. Most solutions are simply variations on the same theme. Principles of distribution can be related to different historic periods and today some may be found obsolete or of historic interest only. Normally, however, the basic theme has permanent validity, whereas the variations lose relevance with the change of political climate.

The individualistic concept of the state comprises different forms of liberalism and utilitarianism. A characteristic of liberalism is that the similarity of taxation to a voluntary exchange transaction is taken as a basis for an equitable distribution of a tax burden given as a function of fiscal concerns. An equitable exchange between state and individual is expected. The benefit principle is given a concrete form in the Lindahl solution that defines the willingness to pay for public services in a way similar to the market pricing of goods and services. A decisive factor in the willingness of the individual taxpayer to pay in weighing private against public consumption is that the marginal tax for each individual citizen must not exceed his or her marginal benefit from the government expenditure, estimated in money terms. ${ }^{3}$

The sacrifice theory developed in the utilitarian world of ideas. Its main tenet is that it is a sacrifice for the individual to pay tax. The tax burden should imply equal subjective sacrifice for the individual. A subjective sacrifice is established according to a common marginal utility curve derived from the decreasing utility of income. The principle of equality in proportional sacrifice opens up for both a horizontal and a vertical interpretation; the minimum sacrifice principle based on equality in marginal sacrifice leads to a vertical concept of equity. ${ }^{4}$

The theory of ability to pay originally emerged from the philosophical idea of the state as a social organism in which there exists a mutual dependency between state and individual. Later, the theory of ability to pay has been taken as a basis for the welfare state view on the distribution of the tax burden. It is a position of strong general validity that the concept of ability to pay is the best expression of the ethical idea of distributive equity in tax law. There are two theoretical interpretations of the theory of ability to pay. One is an equality-

3 Above n 2, 96-97, 99-104.

4 Above n2, 108-115. 
oriented interpretation, implying horizontal equality of treatment, in line with the possible interpretation of the principle of equal sacrifice. The other is an interpretation oriented towards the welfare state, using the concept of ability to pay for the purpose of levelling incomes and net wealth. Regardless of the approach chosen, the measurement of the individual taxpaying capacity should be equal to the amount or degree of private needs satisfaction that the taxpaying citizen can achieve. This position of needs satisfaction can, in turn, be measured in two different ways. One is to compute the satisfaction of needs from the origin side; the other makes the calculation on the usage side. The measurement of the individual's capacity to pay can, accordingly, comprise different acquisitions of means or resources, such as cash income, yield, benefits, and wealth. The taxpaying capacity can also be measured by consumption of goods and services. Regardless of which approach is chosen, the calculation of taxpaying capacity should also be limited to individual capacity in order to target circumstances limiting the individual satisfaction of needs in relation to the economic capacity. In tax theory, it is generally felt that income is practically the best indicator of what represents a person's opportunities for private needs satisfaction. The best method of assessing the real satisfaction of needs, however, is to measure the individual's consumption of monetary and other resources. ${ }^{5}$

The interventionist function of the welfare state is most strongly reflected in the social policy tax theory. Principles of social policy and progression aim to use taxation for equalisation through redistribution of economic resources. The redistribution objective of taxation has been motivated in different ways. Wagner built on the same hypothesis as the marginal utility theory, namely that the subjective utility decreases for every utility unit acquired. He used marginal utility to establish an objective reason for the justification of progressive taxation. Another such reason is that the ability to pay tax increases in a higher proportion than the increase in income. The wealthier one is, the easier it is to increase one's income. A third point of departure is the choice of equality as the ethical foundation for taxation. ${ }^{6}$

\section{B The Principles of Neutrality}

Tax neutrality implies that the distribution of the tax burden should be neutral in relation to economic behaviour and that, for this reason, taxation should be noninterventionist. When discussing the distorting effects of taxes, one should be aware that the concept of neutrality can be understood in different ways, depending on the level at which it is applied and to what it is related. Neutrality principles of tax law must, therefore, be related to the economic policy objective behind them. Neutrality with respect to the

5 Above n 2, 115-124.

6 Above n 2, 127-134. 
allocation of production factors and the principle of competitive neutrality are two principles of tax neutrality which are related to the neo-classical economic policy objectives of a tax system. The first principle is directed towards preventing taxation from impeding economic growth. This principle favours a low tax rate and the avoidance of interventionist taxation in all areas. The other principle expresses the policy objectives of not impeding free competition. Competitive neutrality is one of several conceivable partial neutrality relationships with respect to economic actions. Competitive neutrality can, in turn, be broken down into several aspects. Regardless of competitive relationships, the general interpretation of the principle is that alternatives that are economically of equal value should not be rendered unequal by taxation. ${ }^{\text {? }}$

\section{Domination and Universality of Principles}

The great difference between the equity principles is that the basis for the distribution of tax burden according to the benefit principle, the principle of equality in proportional sacrifice and the ability principle, as opposed to the minimum sacrifice principle as well as the principles of social policy and progression, leads to a horizontal concept of equity. Individuals with equal taxable capacity or equal interest in collective goods should pay the same amount in tax. The approaches of both the minimum sacrifice principle and the social policy oriented principles, in contrast, lead to a vertical concept of equity. For different reasons, individuals with high taxable capacity should be taxed relatively higher than those with low taxable capacity. It is common to interpret the ability principle in this way too, but a diminishing utility approach on the individual taxpaying capacity is questionable.

What can be stated after examining different tax theories is that there is no objective basis for establishing what is an equitable distribution of the tax burden. One cannot use the theory of marginal utility or any theoretical model to establish such an objective foundation. In contrast, the legislator, by taking a position on a matter of legal policy, can decide what should be the basic, ethical norm for an equitable taxation of the income, consumption, or net wealth of individuals. In a pluralistic tax system, where income, consumption, and net wealth form the tax bases for different types of tax, the legislator may choose to justify each form of tax by using different ethical arguments. If taxation has to be neutral with respect to economic actions, it is up to the legislator to choose which economic policy objective or objectives should form the basis of a neutral distribution of the tax burden.

Even though the dominance of some principles cannot be consistently delimited and allocated to definite periods in time, one can still state that the idea of voluntarism in 
taxation and equivalence between the tax payment by the individual and its counterpart in public performance do not constitute a rational basis for the tax system in the welfare state. This idea has therefore been replaced by mandatory taxation in which the principle of ability to pay is seen to be the best expression of the ethical idea of distributive equity in tax law. That the benefit theory has never been allowed to dominate the practical formulation of the tax law does not mean that it is entirely irrelevant. The conflict over how far the tax system should reflect the taxpayer's ability to pay and how much it should regard the benefits the taxpayer receives is always there. What should be stressed here is that one theory of how to distribute the tax burden cannot replace all other theoretical frameworks. The theories of taxation offer different solutions to the question of what the basis for the distribution of the tax burden should be, but no single solution is universal. ${ }^{8}$

\section{How to Apply the Ability to Pay Principle}

As explained above, full normative coherence in relation to the principle of ability to pay requires that the total economic potential for the individual's needs satisfaction is included in the income tax base. Moreover, restrictions on the personal satisfaction of needs, relevant to the ability to pay tax, must be taken into account. This involves three elements. The income tax base has to be broad. Reduced ability to pay caused by high maintenance costs must be taken into account, as well as the use of the individual as the tax unit. The question of tax rates in relation to the ability to pay principle depends entirely on how these three elements are composed. ${ }^{9}$

The trend towards successive broadening of the income tax base based on the HaigSimons concept of income is therefore in line with the view that income is what establishes a person's ability to pay tax. But at the same time it is also important to bear in mind that full adherence to the ability principle demands that the income tax structure consider circumstances that reduce the ability to pay through instruments like deductions or tax credits. The individual is the preferred unit for measuring observed income representing the capacity to pay. In contrast, using the marital unit increases the potential for errors, as the unit's true ability to pay will in part depend upon the correlation between the primary

$8 \quad$ Above n 2, 277.

y See for example M J Boskin, "Factor Supply and Relationship among Choice of Tax Base, Tax Rates and the Unit of Account in the Design of an Optimal Tax System", in HJ Aaron and M J Boskin (eds), The Economics of Taxation, (Brookings Institution Washington, 1980). 
earner's capacity to earn and the number of hours the secondary earner works. ${ }^{10}$ The marital tax unit is therefore seen as a defective indicator of ability to pay. ${ }^{11}$

The equality-oriented interpretation of ability to pay, which has received increasing attention in the tax reform movements of the 1980s and 1990s and among a majority of tax analysts, unanimously supports the full taxation of capital gains. With the Haig-Simons concept of income, horizontal equity will be seriously violated if capital gains are not fully taxed. Differences in the form of income earned and investment opportunities will be reflected in the distribution of the tax burden. Taxpayers with the same economic incomes face the risk of unequal tax treatment. ${ }^{12}$

Global taxation, where all income from whatever source is aggregated and one rate schedule is applied, is consistent with the ability principle. A contrasting structure is the schedular taxation under which each source of income is subject to separate treatment for rate and base. Differentiated tax on different tax objects means that the calculation of tax is removed both from the tax subject and from a unitary assessment of the ability to pay tax. This is in conflict with the core of the principle of ability to pay, namely, a subject-related ability to perform. The whole idea of a direct income tax as the dominating tax form rests on this fundamental assumption. The real effect of the schedular income tax system is to leave the subject-related principle of equal treatment of equal and instead focus on the equal treatment of equal type of tax object.

Using the ability to pay as the one and only normative foundation for progressive income taxation or for a net wealth tax, without adding any further component to the definition of ability to pay tax, is a very questionable approach. In order to motivate a progressive tax, the concept of ability to pay must also include a postulate of diminishing marginal benefit, or some similar argument, that attaches a relatively higher ability to pay to higher incomes than it does to lower ones. This is, of course, perfectly possible as long as it is assumed that the postulate builds on tax policy value judgements and one does not erroneously adopt an obsolete scientific view that promotes the postulate to the level of an economic law of nature. Ability to pay can justify a net wealth tax if net wealth is regarded as a measurement of ability to pay, independent of income. Funded income offers more economic safety and hence more ability to pay than non funded income. Disregarding the

10 P Apps, "Tax Reform and the Tax Unit" (1984) 1 Australian Tax Forum, 472, and J Grbich, "The Tax Unit Debate: Notes on the Critical Resources of a Feminist Revenue Law Scholarship" (199091), Canadian Journal of Women and the Law, 512-514.

11 W Chan, "Taxing the Female - as Woman or Wife?", in C Scott (ed), Women and Taxation (Institute of Policy Studies, Victoria University of Wellington, 1993), 64-65.

12 R Krever and N Brooks, A Capital Gains Tax for New Zealand, (Victoria University Press, Wellington, 1990), 41-44. 
fund theory, net wealth can only represent an independent measurement of ability to pay, if the income and consumption tax bases are limited, and if there is no death or gift duty. This allows for the presumption that net wealth to some extent conveys unused economic capacity.

\section{INCOME TAX BASE}

The existing New Zealand income tax base includes wages and salaries ${ }^{13}$, business profits ${ }^{14}$, returns from assets such as rental income, interest, dividends ${ }^{15}$, as well as some realised gains. ${ }^{16}$ There are two major gaps in the coverage of the New Zealand personal tax base which are not consistent with the ability to pay principle. First, the base does not generally include increases in the market value of assets and imputed income from those assets unless capital gains are realised in the ordinary course of business. Secondly, fringe benefits are excluded from the personal tax base and instead taxed separately, levied on the employers. $^{17}$

Income is not defined in the Income Tax Act, but the courts have, in general, accepted that income is not a term of art and has to be examined in accordance with ordinary concepts and usages of people. ${ }^{18}$ Examination in accordance with ordinary concepts has been transformed into statutes. ${ }^{19}$ At a first glance this could be seen as a very generous approach leading to a very broad definition of income. However, like the courts in all other Commonwealth countries, the New Zealand courts have chosen to restrict the definition of income by excluding capital gains. ${ }^{20}$ Gains of capital nature are not income according to ordinary concepts. ${ }^{21}$

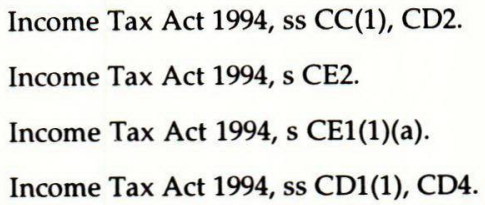
tax. To what extent the employer carries the economic burden depends on the relation between the sensitivity of the employers' demand for labour when labour costs increase and the employees' supply of labour with respect to changes in their real after-tax income. Even so, the structure of levying the tax on the employer is of significant importance when the issue is to determine the fulfilment of the ability to pay principle, which will be developed later.

8 Scott $v$ CT (1935) SR (NSW) 215, 219.

Income Tax Act 1994, s CD5.

Above n 12, 36.

See for example Burnett's Motor Ltd v CIR (1977) 2 TRNZ 359, and J Prebble, Income Tax Law: Concepts and Cases (Butterworths Wellington, 1994), 235. 
In what has become a frequently applied definition of income for tax purposes, Justice Quilliam adopted counsel's submissions about the three principal features of income which had become recognised in the cases. ${ }^{22}$ The first was that income is something which comes in. ${ }^{23}$ The second was that income imports the notion of periodicity, recurrence and regularity. ${ }^{24}$ And the third was that whether or not a particular receipt is income depends upon its quality in the hands of the recipient. ${ }^{25}$ These characteristics of income do not take into account the extent to which a particular receipt is income in terms of adding to an individual's wealth. ${ }^{26}$ That is the typical case with capital gains which often are not realised annually.

\section{A Income $v$ Capital}

The important distinction between ordinary income and capital gains is far from clear as they are not defined in the Income Tax Act. Income from capital falls mainly into one of three categories: ordinary income, which is capital income interpreted under ordinary concepts over the years by judges; income derived from the holding or disposition of an identifiable asset (income on capital account), which traditionally has not been taxable other than in the course of business; and income on capital account which is made taxable by explicit provisions in the Income Tax Act, ${ }^{27}$ provisions dealing with certain land transactions, ${ }^{28}$ certain sales of personal properties ${ }^{29}$, investment income, ${ }^{30}$ and commercial bills. $^{31}$

Except in cases containing such express inclusions, the courts rely on the assumption that only income, and not capital, is taxed. Relying on such an assumption places a difficult task before the courts. Different analogies and statements have been made by the courts to

22 Reid v Commissioner of Inland Revenue [1983] 6 NZTC 61,624.

23 Tennant $v$ Smith [1892] AC 150.

24 FC of T v Dixon (1952) 86 CLR 540, 567-568.

25 Scott $v$ FC of $T$ (1966) 117 CLR 514, 526.

26 New Zealand Government Consultative Document on the Taxation of Income from Capital. (Government Printer, Wellington, 1989), 14.

27 Above n 26, 18.

28 Income Tax Act 1994, s CD 1.

29 Income Tax Act 1994, S CD 4.

30) Income Tax Act 1994, s CE 1.

31 Income Tax Act 1994, s CE 3. 
draw a line between the two concepts. ${ }^{32}$ One of them is the old, well known distinction between the fruit and the tree; capital is compared to the tree and income to the crop. The tree is described as "a reservoir supplied from springs", while the fruit as "the outlet stream, to be measured by its flow during a period of time." ${ }^{.33}$ Traditionally this analogy has been interpreted to immunise capital gains against income taxation. Capital gains are inseparable from the underlying capital assets, and therefore cannot constitute income. Krever is one of those who criticises this traditional distinction of the case. His position is that both income and capital gains constitute income for income tax purposes. The radical conclusion is that expanding the income tax base to embrace capital gains is in line with the United States Supreme Court decision in Eisner v Macomber. ${ }^{34}$

As already noted, among tax analysts and legislators around the world the support for full taxation of capital gains is almost unanimous. Contradictory opinions concern the questions how and when capital gains should be taxed, not if they should be taxed. Should capital gains be treated as ordinary income or be given some preferential treatment? Should they be taxed when realised or as they accrue? The same support is given by several major inquiries in New Zealand.

The first report in 1967, the Ross Committee recommended, with the reservations of moderate tax rates and the implementation of the proposed income tax package in its entirety, that realised capital gains be included in the income tax base. The Ross Committee based its recommendation on grounds of equity, including both the aspect of horizontal equity as well as the ability to pay. The Ross Committee also emphasised that the "absence of a capital gains tax tends to encourage the holding of assets for speculative purposes rather than for productive purposes." Furthermore, it noted that if tax rates were lowered, as it had recommended, then the tax base would necessarily have to be broadened to include capital gains. $^{35}$

In 1982, the opposite position was presented by the so called McCaw Committee, appointed by the Muldoon Government. The McCaw Committee stated that it was "not convinced of the need for a separate capital gains tax...even though capital gains are being made by some which should in principle be taxed. The adoption of the suggestions

32 F Owen The Tax Practitioner 1997 (Butterworths Wellington, 1997), 7-9.

33 The metaphor derives from a decision of the United States Supreme Court, Eisner $v$ Macomber, (1920) 252 U.S. 189.

$34 \quad$ R Krever "The Ironic Australian Legacy of Eisner $v$ Macomber" (1990) 7 Australian Tax Forum, 191206.

35 Report of the Taxation Review Committee Taxation in New Zealand (Government Printer Wellington, 1967), 18, 405-409. 
concerning determination of business income would substantially meet equity requirements. ${ }^{136}$ The basic arguments presented against a capital gains tax were that it would yield little revenue. The small amount of revenue would not justify the substantial complexity which provisions of capital gains would bring into the tax system. The McCaw Committee also concluded that "the introduction of capital gains in a period of high inflation would probably bring with it more inequities than it would cure, unless the effects of inflation were also taken into account." ${ }^{37 "}$

After 1982, several tax analysts and committees have strongly recommended a comprehensive income tax base including capital gains. Some tax analysts are of the opinion that the failure to tax capital gains is a fundamental structural flaw in the New Zealand tax system. ${ }^{38}$ In 1987, a Committee charged to investigate a comprehensive tax reform admitted that tax theory produced strong arguments for making no distinction between income and capital on both the grounds of equity and economic neutrality. The Committee implied that, despite the theoretical, practical and political difficulties, the only satisfactory solution to the problem of taxing capital gains would be a comprehensive proposal. ${ }^{39}$

The Royal Commission on Social Policy, charged to assess how to make New Zealand a more fair and just society, also strongly recommended that capital gains be taxed. In assessing the use of the tax system to reduce disparities in income and wealth the Commission stated:"[v]iewed in terms of fairness (and economic efficiency) the argument for taxing capital gains is overwhelming. ${ }^{40}$

In the 1987 "Post Election Briefing", the incoming Government pointed out the considerable consequences of not including capital gains and losses in income. Difficulties in adequately taxing returns from investment in land, company shares, and unit trusts, reflect the exclusion of capital gains from the income tax base. Moreover, many avoidance schemes exploit the distinction between current and capital income. The Government 1985) 89, A Alston Tax Treatment of Capital Gains in New Zealand, (Victoria University Press Wellington, 1985) 17, and R Stephens "Radical Tax Reform in New Zealand" (1993) 14 Fiscal Studies, 61 .

39 Consultative Committee on Accrual Tax Treatment of Income and Expenditure Comprehensive Tax Reform and Possible Interim Solutions (Government Printer, Wellington, 1987), 4.

41) Royal Commission on Social Policy Working Papers on Income Maintenance Working Paper No 2 (Royal Commission on Social Policy Wellington, 1988), 59. 
planned to address the issue in the accrual regime and in the reform of the taxation of international income. ${ }^{41}$

The July 1988 Budget confirmed the Government's intention to introduce a capital gains tax or, more generally, to improve the system of taxing income from capital. This objective was pursued by the Labour Government with David Caygill as Minister of Finance, after Roger Douglas' departure from the Government. A Consultative Committee was set up and in December 1989, it presented its report. ${ }^{42}$ The document was the outcome of a comprehensive review of the then current tax treatment of income from capital. Its central focus was to identify the aspects of the current treatment that were seen as unfair and inefficient by the Minister of Finance. ${ }^{43}$

The Committee stated that the exemption of a wide range of "income on capital account" (including so-called "capital gains"), was largely a result of historical developments by the courts. The distinction between taxed and untaxed income was extremely difficult to draw and was not related to the way people view investment decisions or their own economic position. The original judicial distinction between ordinary income and capital income had therefore been considerably modified over a long period by specific statutory provisions that were narrowly focused and produced anomalies between different taxpayers and different types of transactions. Taxing some forms of income on capital account while leaving other forms untaxed merely shifts the boundary between taxed and untaxed income. This creates problems on the new boundary. The lack of adjustment for inflation in calculating taxable income was also a main problem pointed out by the Committee.

Concluding that the exemption of certain forms of income on capital account was a serious deficiency that undermined the fairness of the tax system, increased its costs and discouraged productive investments, the Committee proposed to remove most of the exemptions ${ }^{44}$ However, the commitment to improving the taxation of income from capital was shelved before the 1990 General Election. With Labour's, defeat the matter lapsed. ${ }^{45}$

41 New Zealand Treasury Government Management, Brief to the Incoming Government Vol I, (Treasury Wellington, 1988) 301-302.

42 C Sandford Successful Tax Reform, Lessons from an Analysis of Tax Reform in Six Countries (Fiscal Publications Wiltshire, 1993), 57-58.

43 New Zealand Government Consultative Document on the Taxation of Income from Capital (Wellington, 1989), preface I.

Above $n$ 43, 305-306.

Aboven 42, 58. 


\section{B Fringe Benefits}

The Haig-Simons definition of income as the net accretion of a spending unit's power to consume over some period of time, without distinctions as to source or use, includes both money, and anything that could be valued in terms of money. ${ }^{46}$ It is the increase or accretion of the taxpayer's power to satisfy his or her wants, the so called accretion principle, that should be included in the income tax base. The definition embraces all types of receipts, in cash or in kind. ${ }^{47}$ An important part of the employment remuneration system is the non monetary advantages provided to employees in addition to wages and salaries. If these fringe benefits are not subject to tax, there will be substantial economic distortions in the form of employee compensation. The share of remuneration in the form of untaxed fringe benefits will inevitable grow larger than the share of cash income leading to erosion of the income tax base. Obviously both horizontal and vertical equity will be violated. ${ }^{48}$

New Zealand introduced a quarterly Fringe Benefit Tax (FBT) in April 1985 to ensure that non-monetary forms of remuneration are subject to tax. However, it is the employer, who provides employees with benefits, who is liable for the FBT. The reasons for this change were mainly fiscal, higher revenue and lower administrative costs. ${ }^{49}$

An employer is defined as a person who pays "source deduction payments" (like salaries and wages, but also extra emoluments or a withholding tax payment). An employee is defined as a person who at any time, now, before or in the future, receives a source deduction payment. ${ }^{50}$ When first introduced, the FBT was $45 \%$ of the taxable value of fringe benefits. Today the rate is $49 \%$ and the FBT is deductible by the employer on an accrual basis, meaning that the effective rate is $33 \%$ for taxpayers, equivalent to the top personal tax rate. ${ }^{51}$

The New Zealand FBT identifies five main categories of taxable fringe benefit: the private use of motor vehicles; low interest loans; free and discounted goods and services; employer contributions to superannuation, sickness, accident and death benefit funds; and

46 R M Haig, "The Concept of Income - Economic and Legal Aspects" in R M Haig, (ed) The Federal Income Tax (New York, 1921), 7.

47 D J Collins "Taxation of Fringe Benefits - An Economist's Perspective" (1987) 4 Australian Tax Forum, 97-98.

48 C Scott "Taxing Fringe Benefits: The New Zealand and Australian Experience" in C Sandford (ed), Key Issues in Tax Reform (Fiscal Publications, Wiltshire, 1993) 22 and 35-36.

49 Above n 32, 21-22, and Above n 43, 36-38.

50 Income Tax Act 1994, s OB 1.

51 Income Tax Act 1994, s ED 2. Also above n 32, 21-12 and above n 48, 24. 
lump sum retiring allowances and some categories of redundancy payments. ${ }^{52}$ Even if the tax base covers most fringe benefits provided by employers to their employees, it is still not consistent with the ability to pay principle. By imposing the FBT on the employer, a large part of the individual's total potential for needs satisfaction is excluded from the personal income tax base. Both horizontal and vertical equity demand a tax structure based on subject-related ability to perform, which is what the concept of global taxation supplies. All income has to be calculated and imposed on the individual taxpayer, and one rate schedule applied. A split in the individual's tax capacity, such as the FBT, opens up the potential for unequal treatment of taxpayers in similar economic circumstances, particularly where more than one marginal tax rate exists. ${ }^{53}$

\section{The Tax Unit}

New Zealand's tax system has been largely designed around the individual as the unit of assessments, a fact that makes New Zealand unusual compared to most other OECD countries. Marriage or de facto relationship does not influence tax liabilities, except when couples have dependent children. Different types of tax credits for family support use the aggregate parental income to determine the size of the tax reduction. This means that the unit of assessment for income tax is, as a main rule, free from presumptions such as the dependency of women on their husbands' income or that married people are better able to pay tax because they are married rather than single. ${ }^{54}$

New Zealand's most comprehensive tax reform policy statement on the unit of taxation was the McCaw Report from 1982. The report recommended adopting a marital tax unit because, in the absence of joint filing of aggregate income, principles of tax equity were offended. At the horizontal level, family units of equal income were not taxed similarly, preferences being given to those family units with more than one earner. The Task Force saw the married couple as the appropriate tax unit because the inherent economies of living together increase a couple's welfare and its ability to pay. ${ }^{55}$ In the search for the ideal horizontal equity between couples, the McCaw Report came up with a proposal which would favour married couples with a considerable disparity in individual incomes over other taxpayers. Typically, disparity will be greater when the secondary income-earner does not work full-time, in which case there will already be error in the observation of

Income Tax Act 1994, s CI 1.

Above n 48, 36-38.

S St John "The Tax/Benefit Interface" in Scott above n 11, 135-136.

Above $\mathrm{n} 36,95$. 
ability to pay. Despite the recommendation in the McCaw Report, the legislative response has been to maintain the individual as the appropriate tax unit. ${ }^{56}$

\section{Tax on Wealth}

As described above, the ability to pay principle could hardly be used as a normative foundation to advocate a net wealth tax, unless the income tax base is limited, which is the case for New Zealand. New Zealand has no annual tax on the stock of wealth. No estate duty is payable on the estate of any person dying on or after 17 December 1992. The Estate Duty Abolition Act 1993 abolished estate duty by reducing the rate to nil. The legislation, however, remains in place. The only existing tax on wealth is a gift duty on wealth transfers. The Government at one stage announced its intention to repeal gift duty if appropriate measures could be found to avoid unlimited gifting as an instrument for tax planning, or to avoid abuse of targeted social welfare payments. This has not occurred and may never occur. ${ }^{57}$

Substantial exemptions meant that the majority of land in New Zealand remained outside the tax base, giving rise to distortions and unfairness in its application. The estate duty was as Sandford put it, a sorry spectacle, based on the wrong principles for a death duty. ${ }^{58}$ The Government faced the alternative of either broadening the base to include land currently exempt or abolishing the tax. ${ }^{59}$ The land tax issue in New Zealand demonstrates the interaction among political factors, property market forces, and tax system reform. When inflation, and a property boom produced by the global financial deregulation, tested the tax's political and economic viability, abolition not reform was the unexpected outcome. The New Zealand abolition of land tax is judged as an atypical response to the policy problem of dealing simultaneously with land taxation, inflation, and the taxation of capital gains; this approach is not likely to be repeated elsewhere. ${ }^{60}$

Without an annual wealth tax or inheritance-type of wealth transfer tax, or a comprehensive income tax base including capital gains, a large part of the net accretion of assets and imputed income from those assets will remain untaxed. This is an anomaly in a tax system based on the ability to pay principle. In order to achieve horizontal equity, Sandford has proposed the introduction of an annual wealth tax in New Zealand with

Chan, above $n 11,54,63$ and 65.

Above $n$ 32, 25-2.

C Sandford Taxing Wealth in New Zealand (The Institute of Policy Studies, Wellington, 1987), 48.

D Caygill Budget Announcements (New Zealand Government Wellington, 24 July 1990), 107.

B F Reece "The Abolition of Land Tax in New Zealand. Searching For Causes And Policy Lessons" (1993), 10 Australian Tax Forum, 242-244. 
moderate rates on a relatively broad base. He has also proposed a complementary accessions tax to replace the former estate and the present gift taxes with the intent to reduce inequalities in wealth-holding. ${ }^{61}$

\section{E Income Support Through the Tax System}

There have been different types of financial assistance available to families in New Zealand. A common objective throughout has either implicitly or expressly been the prevention of poverty, investment in children, and the horizontal redistribution of income. Measures implemented have included allowances, tax exemptions and rebates, minimum wages, and benefits. ${ }^{62}$ Presently the principal forms of assistance are family support, guaranteed minimum family income, childcare subsidy, domestic purposes benefit, widow's benefit, orphan's benefits, and unsupported child's benefit. ${ }^{63}$ The low income earner rebate (LIR) for New Zealand resident taxpayers in receipt of non-investment income is also part of the family assistance programme. In addition to the tax relief provided to low income earning individuals, by way of LIR and the transitional tax allowance, significant financial assistance is also provided to low and middle income earning families with dependent children by way of the Family Support Tax Credit (FSTC), the Independent Family Tax Credit (IFTC) and a Guaranteed Minimum Family Income (GMFI). ${ }^{64}$ Assistance is administered by the Department of Social Welfare (DSW) to welfare beneficiaries, and by the Inland Revenue Department (IRD) to low-income families. ${ }^{65}$ The Family Support Scheme took effect from 1 October 1986 and included the FSTC and GMFI. Depending on circumstances, families may be eligible for both forms of assistance. FSTC function as an income supplement to both working and non-working families, whereas GMFI is not available to those people receiving an income-tested benefit. ${ }^{66}$ The FSTC can be categorised as vanishing credits and the GMFI as a form of work-related subsidy. ${ }^{67}$

61 Above n 58, 51.

62 C March "Financial Assistance to Families in New Zealand" in Scott (above n 11, 115.

63 W R Atkin Social Security Law - Suppl 5, New Zealand (Kluwer Law International, The Hague, 1996), 49.

64 Inland Revenue The New Zealand Tax System (New Zealand Government September, 1996).

65 Above $\mathrm{n} 62,115$.

66 Above n 32, 18-5.

67 J R Kesselman Rate Structure and Personal Taxation: Flat Rate or Dual Rate? (Victoria University Press Wellington, 1990), 58. 


\section{F Low Income Earner Rebate: those people receiving an income-tested benefit.}

From 1 July 1997, the bottom tax rate is reduced to 19.5 cents on the dollar and the threshold separating the bottom and the top tax rates increased to $\$ 38,000$. However, the rebate implies that taxpayers who earn most of their income from employment or selfemployment, and all superannuitants, face a tax scale which effectively has three tax rates 15 cents on the dollar for the first $\$ 9,500$ of income, 21 cents on the dollar for income between $\$ 9,500$ and $\$ 38,000$ and 33 cents on the dollar for income above $\$ 38,000$. The middle effective tax rate is a result of the structure of the LIR. The last year's changes concentrated on reducing the second effective tax rate as this is the rate faced by the majority of low-and middle-income earners. It has been reduced by a total of 7 cents on the dollar over a couple of years. ${ }^{68}$ The rebate can be summarised as an earnings subsidy. ${ }^{69}$

\section{G Family Support Tax Credit}

Families are eligible for FSTC based on the number of dependent children and the combined family income. Entitlement is on a graduated scale. ${ }^{70}$ Where the family income is below specified thresholds (the thresholds change depending on the number of children), the entitlement per child is the maximum amount. However, once the family income exceeds the thresholds, the entitlement gradually decreases for each additional dollar of income, until it is finally extinguished. ${ }^{71}$

The 1997 abatement levels, or income test, which set out how a family's income ${ }^{72}$ affects the annual amount of Family Support, made the full amount of Family Support available when family income is below $\$ 20,000$. It reduces at the rate of 18 cents in the dollar of family income between $\$ 20,000$ and $\$ 27,000$, and by 30 cents in the dollar on family income

68 W Birch, Tax Reduction and Social Policy Programme-Details., (1996), 22-24, and Inland Revenue, (1996).

69 Above n 67, 58 .

70 From 1 July 1997 , FSTC up to $\$ 60$ per week is paid for the eldest child and each additional child aged 16 years or over, up to $\$ 47$ for the first or only child aged under 16 years, up to $\$ 40$ for each additional child over 13 years and up to $\$ 32$ for each additional child under 13 years. (Income Tax Act 1994, s KD2(2).)

71 Birch, above n 68, and March, above n 62, 115.

72 In this context a family's income refers just to the income of the principal caregiver and his or her spouse, if any. The incomes of any other family members, such as the child or grandparents living in the house, are not counted as family income for abatement purposes. (Birch, above n 68, 29) 
above $\$ 27,000$ (which means $\$ 1,260$ plus 30 cents per dollar of specified income exceeding $\$ 27,000) .^{73}$

Although income tax liability is based on individual incomes, the amount of FSTC entitlement is based on spouses' aggregated income. Family Support was previously paid to each spouse in equal shares. However, as of the 1991 income year, two-parent families who are living together no longer have their Family Support entitlement split. The full amount of the tax credit is to be paid to the principal caregiver ${ }^{74}$ of a dependent child. ${ }^{75}$ The definition of "spouse" is wide, and includes "relationships in the nature of marriage", including de facto situations but does not include a separated spouse. ${ }^{76} \mathrm{~A}$ two-step approach is used to determine the family income. Firstly, income is calculated using all the provisions of the Act except those dealing with the tax credits. Secondly, this figure is adjusted under S KD 1 in the Act for certain items which must be added to determine entitlement to family support. ${ }^{7}$

The same amount of family assistance now applies to those both in, and out of, the workforce. When FSTC is delivered through the tax system, the level of FSTC abates once income exceeds a particular income level. Social Welfare beneficiaries entitled to FSTC who have no other significant income receive the full amount of support along with payments from the DSW. ${ }^{78}$ The Family Benefit, a non-taxable universal benefit of $\$ 6$ a week per child, was amalgamated with Family Support in 1991/92 so that all family assistance is now reduced against combined parental income. ${ }^{79}$

\section{H Guaranteed Minimum Family Income}

The GMFI is a tax credit that supplements the incomes of low-wage working families with dependent children, from 1 July 1997 up to a fixed amount of $\$ 290$ after tax per week, or $\$ 15,080$ net annual income.$^{80}$ Family Support is payable on top of this. This means that the GMFI is an "after tax" income guarantee and is delivered in the form of FSTC. In these circumstances it becomes a negative income tax. To qualify for GMFI, a solo parent has to be employed for at least 20 hours a week, and a couple has to have a combined total of at

Income Tax Act 1994, s KD2(4) and Birch, above n 68, 28-29.

The principal caregiver is defined in the Income Tax Act 1994, s OB 1, as the person who has the primary responsibility for the day-to-day care of the child.

March, above n 62, 116.

Income Tax Act 1994, s OB 1, and above n 32, 18-5.

Above n 32, 18-5.

March, above n 62, 115-116.

Above n 54, 137.

Income Tax Act 1994, s KD3(2) and (3) and Birch, above n 68, 30.
} 
least 30 hours a week of employment. ${ }^{81}$ This benefit structure carries a very high marginal tax for additional hours of work in either part-time or full-time weeks. It also taxes increases in the worker's hourly or weekly pay rate in proportion to the weeks worked per year. $^{82}$

\section{Independent Family Tax Credit}

In 1996 a new Independent Family Tax Credit was enacted. IFTC is a credit separate from and additional to the income tax rate reductions and increases in Family Support. The IFCT is a simple, single amount ( $\$ 15 /$ week) per child regardless of age. For eligible families, IFTC is payable in addition to Family Support. The combined amount is subject to the same income test that applies to Family Support. The abatement applies to the Family Support amount first, and then, when that has been exhausted, to the IFTC amount. ${ }^{83}$

Through this credit, an extra reduction in taxes is targeted to low and middle income working families who are supporting children and who are not reliant on substantial assistance from income-tested social security benefits, student allowances, New Zealand Superannuation or the Accident Compensation scheme. The purpose behind the new IFTC was mainly to solve two equity problems. The first problem was based on the opinion that low and middle income families with children face higher maintenance costs than households without dependent children. Maintenance expenses generated by full-time employment erode the margin of income from paid work over benefit income. The introduction of IFTC was expected to ease the tax burden on these families. The other equity problem was based on the fact that the system tended to lock people in, discouraging beneficiary families from seeking economic independence. By introducing the new IFTC together with higher rates of Family Support, the Minister of Finance, Bill Birch, hoped to allow families to earn more income before all their family tax relief is used up ${ }^{84}$ It is questionable to regard this as an equity problem; it is more a question of reducing the negative effects on work incentives created by the system. The ITFC scheme must be analysed from the ideology presented by the incoming National Government in October 1990. The Government's policy was to ensure that those in genuine need have adequate access to government assistance and that those who can make greater provision for their own needs should be encouraged to do so. Self-reliance was a key principle in this context. ${ }^{85}$

81

82

83

84

85

Birch, above n 68, 30 and March, above n 62, 116.

Above n 67, 60 .

Income Tax Act 1994, s KD2(3) and (4).

Birch, above n 68, 31-34.

J Boston "The Decent Society? Essays in Response to National's Economic and Social Policies" Boston, and L Dalziel, (eds), (Auckland, 1992), 6-7. See further J B Bolger, R Richardson, and W F 


\section{J Family Support and the Ability to Pay}

Even if stereotyped in structure, these tax reliefs together with the guaranteed minimum income constitute a much more far-reaching attempt to target low and middle income earners with reduced ability to pay tax caused by high maintenance costs, than would a zero-rate bracket in the tax schedule. How the ability to pay principle has been decisive for the development of this structure is unclear. It is obvious that a fairer distribution of the tax burden has been of central concern when initiating the process of increased targeting. However, it seems as if the general policy of targeting benefits has come to dominate the development. How the combined impact of taxes and benefits on the distribution of income meets the ability to pay tax is still an open question.

\section{NEW TRENDS}

The excessive emphasis on efficiency and excess burden based on the almost dogmatic concept of efficiency provided by the optimal tax analysis have been shown to be a dead end for the design of tax systems. To achieve tax neutrality the optimal tax approach in its extreme stresses the need for selectivity and unequal rate taxation. This is contradictory to the comprehensiveness and uniformity of tax treatment called for in the broad-based and rate flattened income tax and direct or indirect consumption tax structure developed during the last fifteen years. Optimal taxation is therefore no longer seen as a constructive guide to tax policy. ${ }^{86}$

A more modest assessment of potential efficiency gains could therefore be expected in tax reform designs at the end of the 1990s and beyond. With increasing social concern over widening inequality and rising unemployment, it would not be surprising if politicians chose to reintroduce social norms as guiding principles for tax legislation. This could invite a return to an intervening income tax structure and increasing support for progressive income taxation. The domination and content of the horizontal equity principle and neutrality principles will be questioned. Another scenario is a new awareness of the necessity to better co-ordinate tax and social welfare structures in order to get people, especially women, out of the poverty trap ${ }^{87}$ and economic dependency and into the

Birch Economic and Social Initiative., Statements to the House of Representatives, (The Government Wellington, 1990).

86 Above n 1, 37, and A A Tait "Not So General Equilibrium and Not So Optimal Taxation" (1989) US Public Finance, and J G Head "Tax Fairness Principles: A Conceptual, Historical and Practical Review" (1992) 9 Australian Tax Forum, 84-97.

87 The situation where the "the combined effect of income taxation and abatement of benefits for any increase in non-benefit income results in beneficiaries or low income earners receiving little or no additional reward for increased work effort." (E Brashares, and J P Smith "Poverty Traps in New Zealand" (1991) 8 Australian Tax Forum, 63.) 
workforce. ${ }^{88}$ The issue of interface between the tax and benefit systems is of great concern in New Zealand. A lack of integration and consistency have emerged from separate developments concerning tax and income maintenance policies. ${ }^{89}$ Many tax analysts are of the opinion that women are particularly disadvantaged by this lack of consistency, ${ }^{90}$ based on the fact that women are over-represented among the poor in New Zealand and heavily dependent on the state as a provider of transfers and services. Women are also the dominant clients of the Income Support Service. ${ }^{91}$

By the early 1980s, the main part of social expenditure in New Zealand, including education, health care, and some forms of income, was largely non-means-tested. The welfare system had primarily been based on a mixture of the residualist and right-based models. The policy shift from the mid-1980s and forward towards a minimal welfare state with a much more targeted social policy regime - a shift rooted in economic depression and neoliberal winds - initiated a radical restructuring of the welfare state. Implemented first by the fourth Labour Government (1984-1990) and then by the incoming conservative Government, the restructuring has involved significant cuts in income support together with a tightening of eligibility criteria. There has been a move away from universal programmes to a more tightly targeted social assistance system. ${ }^{92}$ During the same period, the Labour Government made radical changes in the tax system: a substantial flattening of the tax rate scale and a greater reliance on indirect taxes with the introduction of a comprehensive VAT. The purpose was to reduce the progression in order to minimise the efficiency costs of high effective marginal tax rates $\left(\mathrm{EMTR}^{93}\right.$ ) as they have a negative effect on work incentives.

\section{A Interface Issues and labour market participation of women}

Personal income tax together with social security contributions, clearly play a predominant role in any how taxation may influence social or economic behaviour. However, it is difficult to establish the relationship between taxation and the incentives to

90

Above n 1, 40, and G B Peters The Politics of Taxation: A Comparative Perspective (Blackwell Cambridge 1991), 289.

9 Above n 54, 135.

See Scott, above $n 11$.

A de Bruin "Implications of the Welfare State and Its Restructuring for New Zealand Women: A Feminist Critique" 172-185, in Scott, above n 11, 173.

Boston above $\mathrm{n} 85$ at 5-6 and De Bruin above $\mathrm{n}$ 91, 172.

"EMTR measure how much of an additional dollar of private income is paid to the government in taxes and/or the withdrawal of income tested benefits, and indicate where poverty traps may occur." Above n 87, 63. 
work. A basic problem for any income tax system, the problem of equal importance for work supply, is the question of what the relative treatment of taxpayers in different working and family situations should be.

A woman's economic independence can be measured by the share of family income, which in turn depends on the cross effects of the participation rate of men and women in the labour market, the number of hours worked, the wage ratios of women relative to men, and taxes and social security contributions. Gustafsson and Bruyn-Hundt point out that women's decisions to enter and remain in the labour market are dependent on whether their work increases family after-tax income above what their household production is worth to the family. Gustafsson and Bruyn-Hundt have determined four important factors in looking at the incentives or disincentives of the tax and the social security systems for women's participation in the labour market. The four factors are the choice of the tax unit (joint or separate taxation), the method of determining income, allowances and deductions, and whether the tax rate is linear, progressive, or regressive. ${ }^{94}$ Some examples of these interface issues, traced in the New Zealand tax and benefit systems, are given below.

\section{B Income}

The definition of income has become important for both the social security system and health benefits as there has been a move away from free health care.

The general definition of income in that area provides that income in relation to any persons: ${ }^{95}$

(a) Means any money received or the value in money's worth of any interest acquired, before income tax, by the person which is not capital (except as hereinafter set out); and;

(b) Includes, whether capital or not and as calculated before the deduction (where applicable) of income tax, any periodical payments made, and the value of any credits or services provided periodically, from any source for income-related purposes and used by the person for income-related purposes; ...

The meaning to be given to income for benefit purposes is wider than the meaning normally ascribed to income for income tax purposes. In a recent case, the Judge weighed the principal features of income recognised in the cases ${ }^{96}$ and the wide ranging definition of

94 S Gustafson, and M Bruyn-Hundt "Incentives for Women to Work: a Comparison between the Netherlands, Sweden and West Germany" (1991) 18 Journal Of Economic Studies, 30-31.

95 Social Security Act 1964, s 3(1).

46 The Judge recognised in this context specially the principles stated in Reid $v$ Commissioner of Inland Revenue [1983] 6 NZTC 61, 624. 
income in the Social Security Act, designed to capture all forms of money used to maintenance of person or family. An important point made by the Judge was that an essential quality of income is when the income truly adds to the resources of the person receiving them. In this respect, loans are disqualified as they are available without regard to need in general terms and must be repaid. The Judge also stated that if Government sees taking out a loan to assist with living expenses as disentitling a student to other needsbased social welfare assistance then it should make that plain by clear legislative expression. ${ }^{97}$ This judgment illustrates that an integrated approach is required if the goal is to create a unified definition of income, especially since family support has become an integrated part of the income tax system. It has not been the ambition of this article to provide comprehensive coverage of all types of income definition in tax and social legislation. Despite its limitations, this study has reviewed, from both a substantial and a technical respect, three ways in which income can be defined - the general definition for tax purposes, the definition of family income used to determine entitlement for family support, and the definition in the Social Security Act.

\section{Unit of Assessment}

In contrast to the tax system, the benefit system in New Zealand has traditionally used the couple as the unit of assessment. Thus ordinary social security benefits, such as sickness, unemployment and invalids' benefits, are paid at a lower rate for married persons than for single persons and are assessed according to joint income. The lower rate implies some economies are possible for married people that are not available to people who simply live together. The income test implies income sharing, as an unemployed woman or man may lose all entitlement to the benefit because of their spouses' income. The amount of income exempt from the social security income test is the same for the married couple as for a single person. According to St John this implies a penal treatment of marriage. ${ }^{98}$ On top of this, to determine what is and what is not a marriage-like situation is notoriously difficult question. The applicant for a benefit must not be "living together with her husband or his wife or with the other parent of the child, as the case may be." 99 The words "husband" and "wife" are given an extended meaning to include those who have been living together in a de facto relationship, understood as a relationship in the nature of marriage. The traditional approach to the existence of a de facto relationship involved proof first of actual cohabitation and, secondly of the mental intention evidenced by such factors, weighted 97 Director-General of Social Security $v$ K \& M Unreported, 7 Feb 1996, High Court, Wellington Registry,
AP 255/95.

Above n 54, 135-136.

99

Social Security Act 1964, Section 27B(2)( c), SSA. 
individually. ${ }^{100}$ A good example of this approach is given in Mauri $v$ Department of Social Welfare. A woman was convicted of making false statements with respect to her relationship with a man who came and went from her home as he pleased. The quality of the relationship was very low, the man often being drunk, and not contributing financially. Without more, the judge might have been inclined to say that the relationship was not in the nature of marriage. However, the woman had also borne the man three children. The court took into account other factors such as the length of the relationship, its degree of permanence, living conditions, the existence of sexual relations, financial arrangements, evidence of commitment to the interests of the other, sharing of leisure time activities, how the couple presented themselves to outsiders, and whether the relationship was exclusive of third persons. ${ }^{101}$ However, recently the Court of Appeal in Ruka v DSW adopted a somewhat new approach when deciding that financial interdependence is an essential element in a relationship in the nature of marriage. ${ }^{102}$

Inconsistency also exists within the tax system. As shown above, the family support scheme is income-tested on a joint income basis. The income test is based on the family as a unit for assessment. The abatement of this type of tax credit therefore does not coincide with the rest of the income tax system which is based on the individual as a unit. This family support scheme means that the tax system contains both individual and joint taxation. It is in conflict with the ability to pay principle. Income testing a substitute for a benefit which was previously universally available will effectively increase the marginal tax rate for the secondary earner in the family. It can be expected that the overall impact of the income test will be to encourage further dependency, as well as an efficiency loss to the economy which is all the greater owing to the special sensitivity of labour supply by secondary earners to marginal tax rates. ${ }^{103}$

\section{EMTR and Family Support}

The targeting regimes counteracted the fourth Labour Government's purpose to reduce progression by introducing an almost pure dual rate tax schedule. It is obvious that the targeted combination of low income rebate, credit on top of credit, and guaranteed minimum income raise effective marginal and average effective tax rates above the $19.5 \%$ basic rate for persons at lower to middle incomes, a significant part of the population. The main sources today of high EMTRs are benefit and Family Support abatement and the GMFI, not

See further W R Atkin, Living Together Without Marriage: The Law in New Zealand (Butterworths, Wellington, 1991) 13-29.

101 (1987) 4 NZFLR 481.

1112 [1997] 1 NZLR 154.

1113 Chan, above $n 11,67$. 
the income tax scale in itself. ${ }^{104}$ In fact, many low income earners face higher average effective tax rates than higher income individuals do. For low income individuals who receive significant net benefits the tax system therefore is regressive. ${ }^{105}$ This shows the tensions between trying to minimise the cost of tax expenditures providing horizontal equity between different sizes of family, providing an adequate minimum income, ensuring vertical equity, and minimising the efficiency costs of high effective marginal tax rates. ${ }^{106}$

The National Government has tried to overcome the EMTR problems. One of the most far reaching proposals was presented by the Change Team on the Targeting of Social Assistance, set up by the Government to design a new and integrated system. The policy document that emerged ${ }^{107}$ was the background paper for the wide-ranging reforms announced in the 1991 budget where two new concepts were introduced, the "core family" and "family accounts". All income support would be based on a single income test, a single income exemption, a single rate and uniform abatement levels. For this global system the core family should be the new unit of assessment. ${ }^{108}$ However, the definition of a family unit could not be translated to a workable practical solution for welfare abatement. In mid1993, it was announced that the work on family accounts had been abandoned. However, implementation of more tightly targeted welfare policies proceeded. ${ }^{109}$

Conclusions made by Inland Revenue predict that the high effective marginal tax rates facing low income earners on benefits reduces the overall efficiency of the tax system, and that the equity implications can be interpreted as such as the EMTRs mean that redistribution in the current family support tax credit regime has become inefficient. Targeting benefits for equity and fiscal cost reasons need, therefore, to be weighed against the potential efficiency costs associated with imposing relatively high effective marginal tax rates on beneficiaries. ${ }^{110}$

It is obvious that the combination of the flattening of income tax rates and an increase of targeted benefits have been disadvantageous for women in their role as secondary earners

Above n 87, 77-78 and above n 67, 58.

Inland Revenue, Supplementary Briefing Paper, Vol 2, (October 1996).

Stephens, above $\mathrm{n} 38,50-51$ and 61.

Change Team on Targeting Social Assistance, Report of the Change Team on Targeting Social Assistance. (Wellington, 1991).

Jenny Shipley et al Social Assistance. Welfare that Works a Statement of Government Policy on Social Assistance (New Zealand Government, Wellington, 1991).

Above n 54, 138-140.

Inland Revenue, Supplementary Briefing Paper, Vol 2, (October 1996). 
in households with dependent children or in their role as solo mothers. The legislators have failed to design an income tax system with a uniform and consistent definition of income. Another inconsistency is that the individual as a unit of assessment is not generally applicable. St John predicts further complexities if the trend of using different definition of incomes for specific targeting measures to reduce gross inequities remains. ${ }^{111} \mathrm{I}$ am prepared to agree. The picture becomes even more complex if one consider that the income tax base is not as comprehensive as would be desirable from an ability to pay perspective. This means that a taxpayer receiving tax relief based on the Family Support scheme may have an untaxed economic capacity derived from income like capital gains. The existing situation suggest that a closer consideration of what and whose ability should be targeted would be a fruitful strategy in future tax reforms.

$111 \quad$ Above $\mathrm{n}$ 54, 135, 140 and 145. 